\title{
HUNYADI SÁNDOR
}

hunyadi.sanyi93@gmail.com

PhD-hallgató (ELTE BTK Történelemtudományi Doktori Iskola)

\section{Az erdélyi püspökség és székeskáptalan Kán László vajdasága alatt}

\author{
The Chapter and the Diocese of Transylvania in the reign of \\ Ladislaus Kán, Voivode of Transylvania
}

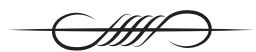

\begin{abstract}
The episcopacy played an important role at the end of the Arpad Age, and the fate of certain dioceses were sealed by the relationships between the bishops and the oligarchs. Thus, at the end of the $13^{\text {th }}$ and at the beginning of the $14^{\text {th }}$ century, both the history of the Chapter and of the Diocese of Transylvania was heavily influenced by the relation between Bishop Peter Monoszló and Ladislaus Kán, Voivode of Transylvania. In my article, I aim to survey the relationship of the Diocese and the Chapter of Transylvania, beginning with Bishop Peter Monoszló, with the later Voivode of Transylvania, Ladislaus Kán, elaborately presenting the signs which may imply a harmonic relation between the bishop and the voivode, the economic conflict with the chapter, and the difficulties the chapter had to face following the death of Peter Monoszló: the difficult election and confirmation of his successor, Bishop Benedict, and the lawsuits against the Transylvanian Saxons.
\end{abstract}

\section{KEYWORDS}

Chapter of Transylvania, Diocese of Transylvania, church history, voivode of Transylvania

DOI 10.14232/belv.2021.1.3

https://doi.org/10.14232/belv.2021.1.3

Cikkre való hivatkozás / How to cite this article:

Hunyadi Sándor (2021): Az erdélyi püspökség és székeskáptalan Kán László vajdasága alatt. 
Belvedere Meridionale vol. 33. no. 1. 19-46. pp

ISSN 1419-0222 (print)

ISSN 2064-5929 (online, pdf)

(Creative Commons) Nevezd meg! - Így add tovább! 4.0 (CC BY-SA 4.0)

(Creative Commons) Attribution-ShareAlike 4.0 International (CC BY-SA 4.0)

www.belvedere-meridionale.hu

A tizenharmadik század, s különösen annak utolsó harmada a Magyar Királyságban tartományuraságok, oligarchahatalmak kialakulásának az időszaka volt. Ezek kialakulása szempontjából két legfontosabb bázisuknak egyrészt a világi nagybirtok tekinthető, amely elsősorban a foglalások révén erősödött meg, másrészt pedig a tizenharmadik század második felében megerősödött magánfamília. Ezek mellett az oligarcháknak ${ }^{1}$ volt valamilyen közjogi méltósága is, amelyet betöltöttek - Kán nembeli László esetében ez az erdélyi vajdai és a szolnoki ispáni cím -, mindezek jogi mázt adtak magánjellegű intézkedéseiknek, ${ }^{2}$ amelyek a törvényes formákhoz mindig is jobban ragaszkodó egyháziakkal szemben bizonyultak fontosnak. Ha azonban az oligarchák és az erdélyi egyház viszonyáról szeretnénk átfogó képet kapni, akkor, bár hazai történetírásunk alaposan körüljárta az oligarchák és tartományaik kérdését, nincs olyan tanulmány, amely kimerítő választ adna a kérdésünkre. ${ }^{3}$ Jelen írás tárgya ezért elsősorban Kán nembeli László és az erdélyi egyházak - különösen az erdélyi püspökség és az erdélyi káptalan - kapcsolata vajdaságának mintegy 20 éve alatt.

\section{KÁN NEMBELI LÁSZLÓ ÉS AZ ERDÉLYI PÜSPÖKSÉG}

IV. Béla és V. István küzdelmét követően a magyarországi egyházak igen keserves tapasztalatokat szereztek az anarchiáról, elsősorban a maguk kárán, nem csoda tehát, hogy a föpapok közül kerültek ki azon csoportosulások vezetői, akik megelégelték az ország romlását. Ennek első lépéseként 1277-ben nagykorúvá nyilvánították IV. Lászlót, aki esküt tett a béke megbontóinak

\footnotetext{
A tartományúr és oligarcha fogalmának szétválasztására Zsoldos 2012. 347-354. Ezt a terminológiai megkülönböztetést használom jelen dolgozatban is, azonban az oligarchák territóriumait, a körülményes kifejezéseket kerülendő, tartományuraságnak nevezem. Jelen dolgozatban ezt a kényelmetlennek nevezhető terminológiai helyzetet az oldja fel, hogy a tartományuraságként csak a Zsoldos Attila által bevezetett oligarcha fogalomnak megfelelő személyek territóriumait nevezem.

2 KRISTó 2002. 312.; Kán nembeli László nevében 18 oklevél vagy oklevélemlítés maradt fent, ezek mindegyikében szerepel László erdélyi vajda és a legtöbben szolnoki ispáni címe. Ez is mutatja, hogy hatalmának közjogi méltósága adott legalitást (Kristó 1983. 283.)

3 Kristó Gyula alapvető munkájában ugyan tárgyalja a tartományurak és az egyház viszonyát, de csak röviden. KRISTó 1979. 172-178. A román történetírás sokat emlegette Kán nembeli Lászlót, mert a korábbi évtizedekben, de olykor még manapság is, az Erdély és Magyarország feltételezett külön fejlődésének exponensét látta benne. Kritikájára lásd: KRISTó 1983. 294-299.; Legújabban Tudor Sălăgean foglalkozott Kán nembeli Lászlóval, azonban a román történetírás az egyházi viszonyokra sokkal kevesebb figyelmet fordított (SĂLĂGEAN 2007., magyar nyelvủ ismertetésére lásd: HEGYI 2010.a).
} 
rendszabályozására. ${ }^{4}$ Forrásaink rámutatnak arra, hogy a bencés apátságok mennyire ki voltak téve a világiak foglalásainak, hatalmaskodásainak, nem egyszer azt is lehetetlenné téve, hogy törvényes apát kerüljön egy-egy apátság élére. Az 1279. évi budai zsinat többek között arról rendelkezett, hogy világi embereknek tilos a javadalmakat saját embereik számára lefoglalni. Így a nehéz állapotok között jóformán magukra maradtak az egyes apátságok. ${ }^{5}$ Balázs, a veszprémi egyházmegyében fekvő Almád apátja 1282-ben arról panaszkodott a veszprémi káptalan előtt, hogy az elmúlt időszak háborúskodásai miatt monostora végső szegénységre jutott. ${ }^{6} \mathrm{Az}$ Árpád-kor végére, különösen III. András uralkodása alatt, valamint a halálát követő interregnum idején a magyar püspöki kar jelentős szerepet töltött be. Kovács Mihai megjegyzi, hogy ,anyagi helyzetük, spirituális tekintélyük, kiváló képzettségük, nem utolsósorban egységes fellépésük révén a magyar püspökök még a trón betöltését vagy a királyság külpolitikai orientációját is tudták befolyásolni."’7 A Magyar Királyság püspökeinek, illetve hatalmuknak a jelentőségét mi sem mutatja jobban, minthogy már az 1270es években világi érdekcsoporthoz kötődő püspökök voltak az egyházi előkelők soraiban, például „Kőszegi” Péter veszprémi püspök, Kán nembeli Miklós, Kán nembeli László nagybátyja, aki erdélyi kanonokból lett választott esztergomi érsek. ${ }^{8}$ De ide vehetjük a bennünket különösen érdeklö Monoszló nembeli Péter erdélyi püspököt is. ${ }^{9}$ III. András uralkodása alatt tovább növekedett a püspökök befolyása, ${ }^{10}$ ugyanakkor már egy másik folyamat is megfigyelhetö. A király és a királyné támogatását is élvező Balog nembeli Pál pécsi püspök ${ }^{11}$ esetében az uralkodói segítség mellett a Baranyában tartományúri hatalom kiépítésére törekvő Köszegiek támogatását is bírnia kellett megválasztásához, sőt későbbi adatok is szólnak a püspök és az oligarcha együttmüködésérőll. ${ }^{12}$ Ez utóbbi jelenség összefügg azzal, hogy a 13-14. század fordulója táján élessé vált politikai pártharcokban a hatalmi befolyás és presztízs növelése egyik hatásos módjának számított az egyházi élet irányítása, illetve a felette megszerzett világi ellenőrzés. ${ }^{13}$

Hasonló folyamatok figyelhetőek meg Erdélyben is. Kán nembeli László erdélyi vajdai titulusára a legkorábbi említésünk 1295-böl van. ${ }^{14}$ A fentebb említettekből következik, hogy az erdélyi káptalan történetét ebben a korszakban a püspök és az erdélyi vajda kapcsolatának keretében kell értelmeznünk. Azonban ahhoz, hogy megérthessük és tárgyalhassuk a vajda és az ekkor erdélyi püspöki székben ülő Monoszló nembeli Péter kapcsolatát, röviden át kell tekintenünk a püspök életét.

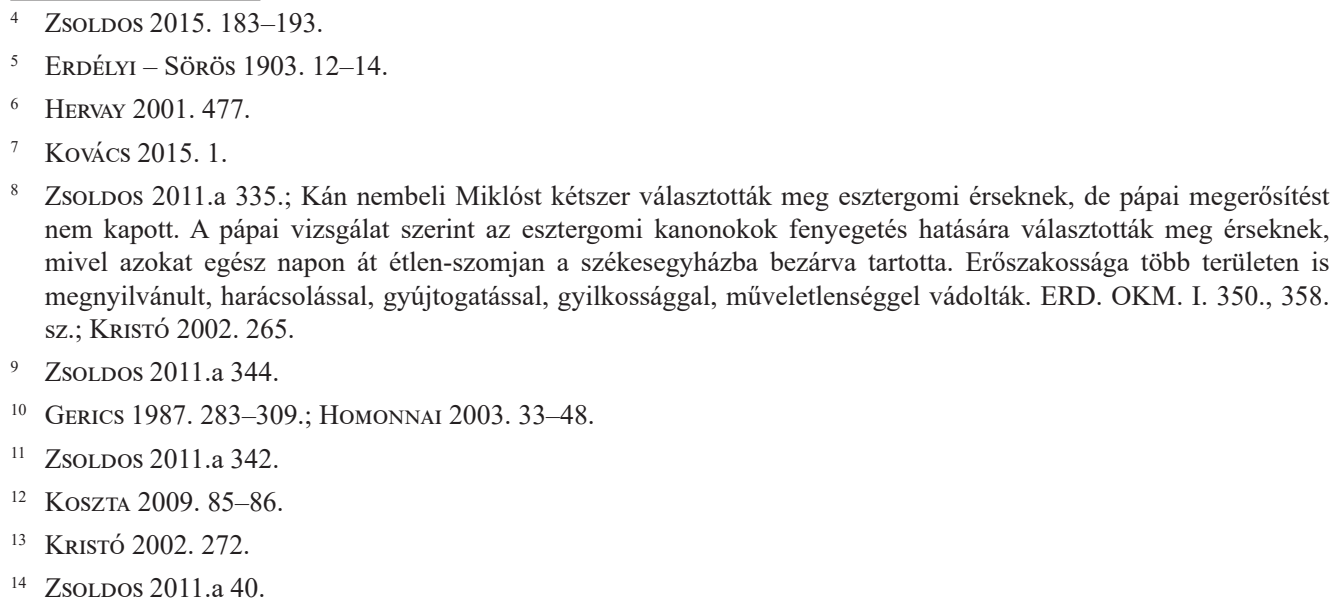

Zsoldos 2011.a 335.; Kán nembeli Miklóst kétszer választották meg esztergomi érseknek, de pápai megerősítést nem kapott. A pápai vizsgálat szerint az esztergomi kanonokok fenyegetés hatására választották meg érseknek, mivel azokat egész napon át étlen-szomjan a székesegyházba bezárva tartotta. Erőszakossága több területen is megnyilvánult, harácsolással, gyújtogatással, gyilkossággal, műveletlenséggel vádolták. ERD. OKM. I. 350., 358. SZ.; KRISTÓ 2002. 265.

9 Zsoldos 2011.a 344.

10 Gerics 1987. 283-309.; Homonnai 2003. 33-48.

11 ZsOLDOS 2011.a 342.

12 Koszta 2009. 85-86.

13 KRISTÓ 2002. 272.

14 Zsoldos 2011.a 40. 
Péter Monoszló nembeli Gergely fia, két testvérével, Egyeddel és Gergellyel V. István embereiként tűntek fel az 1260-as években, fényes karriert futottak be, és a király haláláig fontos udvari tisztségeket viseltek. ${ }^{15}$ Péter 1266-tól az ifjabb király alkancellárja, majd 1270-től erdélyi püspök volt. Bár családja hatalmának csúcspontját V. István uralkodása jelentette, Péter ezt követően is aktív részese maradt a magyarországi politikai életnek. 1270. május 2. előtt választott erdélyi püspök, június 13-ára már a pápai megerösítést is elnyerte. ${ }^{16}$ Már $\mathrm{V}$. István uralkodása alatt az erdélyi egyház korábbi kiváltságainak megerősítését kérte, valamint újabb adományokat szerzett a királlyal való személyes kapcsolatait kihasználva, nemcsak a püspökség, hanem a káptalan számára is. ${ }^{17}$ IV. László uralkodásának elején Péter püspök testvérei lázadásának köszönhetően rövid időre háttérbe szorult és nem számíthatott a trón támogatására, de 1275ben már újra kéréssel járult a királyhoz ${ }^{18}$ egy korábbi adomány megerösítését kérvényezve. ${ }^{19}$ Ezen oklevél alapján Péter püspök már 1270-1272 között megkapta adományként Kolozsvárt, így a püspökség birtokaival két tüz közé szorította a kolozsmonostori apátságot, és egy olyan birtokcserét kényszerített ki, amelynek köszönhetően Kolozs megye nyugati felében összefüggő püspöki uradalom jöhetett létre. ${ }^{20}$

Ezt az időszakot követte az erdélyi püspökség védelmi erejének fokozása, Péter püspök várszerzési és -építési programja. ${ }^{21}$ Az erdélyi egyházfő nem elégedett meg a korszerütlen ispánsági földvárakkal, kővárakat építtetett. 1276-ban a káptalantól haláláig vagy addig, amíg az erdélyi püspöki székben ült, megkapott tótfaludi magaslaton megkezdte Szentmihálykö várának építését. ${ }^{22}$ Szintén ekkor (1282-1300 között) épülhetett a szászfenesi ún. Leányvár. ${ }^{23}$ Véleményem szerint a püspök véderejének fokozása mögött nem kell konkrét ellenfelet látni, a korszakban a várépítés elengedhetetlen tartozéka volt az alakuló birtoktömböknek, márpedig 15 Zsoldos 2011.a 299., 304.

16 ERD. OKM. I. 284. sz.

17 Uo. I. 287., 291., 310., 315. sz.; TeMESvíRY 1922. 53.

18 Kovács 2015. 2.; Temesváry 1922. 55.

19 ERD. OKM. I. 298., 339. sz.

${ }^{20}$ JAKÓ 2001. 107.; Ha figyelembe vesszük Jakó Zsigmond azon érvelését, amely szerint a kolozsmonostori bencés apátság a tatárjárás során elpusztult és csak az 1280-as években alapították újra és népesítették be szerzetesekkel (JAKó 1990. 20-24.), akkor az sem zárható ki, hogy az 1270-1272 között kapott birtokadomány az erdélyi püspöki birtokok terjeszkedésének új irányát jelöli ki, azaz Péter püspök célja az egykor az apátság birtokában levő földek megszerzése lehetett. Az apátság ügyében való tisztánlátást nehezíti, hogy Moys fia Moys lázadása idején Ákos nembeli Berzethe János elfoglalta Kolozsmonostort, apátját fogságra vetette, valamint az apátság okleveleit elpusztította (Uo. 25-26.). Így a tizenharmadik század végéig hiteles forrásokkal nem rendelkezünk az apátságot illetően.

21 Kovícs 2015. 12.

22 ERD. OKM. I. 341. sz.

${ }^{23}$ Kovács Mihai megjegyzi, hogy ,a püspöki várak építése ebben a korszakban valószínüleg a püspökség klasszikus ellenfeleinek, a szász közösségnek és a kolozsmonostori apátságnak az ellenőrzésére irányult" (Kovács 2015. 12.). Bár a korábbi időszakban nem példátlan az erdélyi püspökök és a kolozsmonostori apátság összetűzése (ERD. OKM. I. 122. sz.), Kovács érvelésének ellentmond Jakó azon megjegyzése, amely szerint a tatárjárás idején elpusztult monostort 1280 táján telepíthették be újra, és népesíthették be ismét szerzetesekkel, azonban az első hiteles adatunk 1299-ből maradt fenn. (Uo. I. 584. sz.; JAKó 1990. 20-24.). Így a szászfenesi ún. Leányvár építésének hátterében véleményem szerint nem az amúgy is meggyengült bencés apátság elleni védekezés szándéka állt, hanem - ahogy azt Tudor Sălăgean is megjegyezte - a jó stratégiai elhelyezkedés volt a fontos, különösen a káptalan birtokainak védelme szempontjából. (SĂLĂGEAN 2016. 171.) Fügedi Erik szerint lehetséges, hogy Leányvár építése a Szamos menti rablóvárak lerombolásával állt kapcsolatban, amiért IV. László király jutalomban részesítette az erdélyi püspököt. (FÜGEDI 1977. 133.) 
mind az erdélyi káptalan, mind a püspökség jelenléte meghatározó a térségben. ${ }^{24} \mathrm{~A}$ fentiek mellett az is feltételezhető, hogy amikor Lodomér váradi püspök, a későbbi esztergomi érsek konfliktusba került a Geregyékkel, az erdélyi püspök, mint szövetségese támogatta az ellenük induló királyi hadakat. ${ }^{25}$

Az 1277. évi szász támadást követően az erdélyi püspökség és a káptalan több ízben kapott adományt a királytól. 1279 nyarától 1280 októberéig Péter Budán, majd Esztergomban tartózkodott Fülöp fermói püspök, legátus, ${ }^{26}$ illetve Lodomér esztergomi érsek oldalán. 1282. évi okleveles adatunk szerint Péter püspök kérésére IV. László nemcsak megerősítette IV. Béla és V. István korábbi adományát, hanem ki is terjesztette azt, a püspökség összes birtokára. ${ }^{27}$ Így az erdélyi püspök birtokán élők mentesültek a vajdai és más megyésispánok joghatósága alól. ${ }^{28}$ 1287-ben Lodomér megbízta Péter erdélyi püspököt, hogy használja fel a lelki hatalmát a királyné jövedelmeinek a visszaszerzésére, s az esetleg vonakodó beszterceieket egyházi tilalommal sújtsa. ${ }^{29}$ Szintén 1287-ben helyezte az erdélyi székeskáptalan élére rokonát, Bö nembeli István fia Mihály mestert, hogy kézben tartsa a testületet és támogassa az egyházmegye kormányzásában. ${ }^{30}$

Jól jellemzi Monoszló nembeli Péter habitusát az ugocsai tized ügye. II. András uralkodásától az egri püspök joghatósága alá tartoztak az ugocsai, beregi és máramarosi területek. Később ezt erősítette meg IV. Béla, majd V. István is. Azonban, amikor 1288-ban Borsa nembeli Kopasz bitorolta az ugocsai tizedet, Péter püspök perre vitte a tized ügyét, amit IV. László (vélhetően a máramarosi tizeddel együtt) az erdélyi püspöknek ítélt. ${ }^{31}$ Az ügy itt nem ért véget. A 13. század végén jelentős népesség települt ide, feltehetőleg az egri püspökség területéröl. A várható tizedjövedelmek miatt Hontpázmány nembeli András egri püspök kijárta III. András királynál, hogy rendelje a máramarosi területet az ö joghatósága alá. 1299-ben Péter püspök amiatt panaszkodott, hogy András egri püspök temetőket szentel Máramarosban, ami jog szerint az erdélyi püspököt illette. III. András először az egri püspöknek ítélte Máramarost, majd az erdélyi püspök tiltakozása miatt visszavonta döntését, a kalocsai érsek elé (mint metropolita elé) utalva az ügyet. Az egri püspök azonban nem jelent meg a kalocsai érsek elött, majd a helyi nemesség körében tartott vizsgálatot követően a király az erdélyi püspök joghatósága alá utalta a területet. ${ }^{32}$ András püspök újabb eljárást indított, erre válaszul Péter erdélyi püspök a Szentszékhez fellebbezett. Ezt azzal indokolta, hogy világi bíróság nem ítélhet egyházi ügyekben. ${ }^{33} \mathrm{~A}$ per további lefolyása okleveles adatok híján nem rekonstruálható, Máramaros, Bereg és Ugocsa északi része kisebb megszakításokkal a középkor végéig az egri püspök joghatósága alatt maradt, Ugocsa déli része pedig az erdélyi egyházmegyéhez tartozott. 1346-ban Szécsi András püspök még

24 Kovács 2019. 298-299.

25 Kovícs 2015. 7.

26 Fermói Fülöp legátus személyére, tevékenységére Kovács V. 2019.

27 ERD. OKM. I. 391. sZ.; TEMESVÁRY 1922. 69-70.

28 Az erdélyi vajdák joghatóságára JANITS 19-29.

29 MES II. 224-225.; ERD. OKM. I. 431. sz.; TEMESVÁRY 1922. 74-75.

30 Uo. 85.

31 ERD. OKM. I. 440. sZ.; KovÁcs 2015. 7., 9.; TEMESváRY 1922. 77-79.

32 DF 277 216.; ERD. OKM. I. 581. sz.; TeMESVÁRY 1922. 94-95.; A joghatósági vita előzményeire KRISTó 1988. 493-497.

33 ERD. OKM. I. 592. sZ.; TEMESVÁRY 1922. 96. 
tett egy kísérletet Máramaros visszaszerzésére, ${ }^{34}$ de az 1332-1337 közötti pápai tizedjegyzék adatai szerint Máramaros már az egri püspökséghez tartozott. ${ }^{35}$ Esetünkben azonban nem a per végkimenetele a leglényegesebb, hanem az, ahogy annak menete fényt vet Monoszló nembeli Péter udvari befolyására, egyházjogi jártasságára és széles körű kapcsolataira. ${ }^{36}$ Ugyancsak 1288. évi adat szerint Péter püspök megszerezte Mikola fiainak bizonyos birtokait, amíg azok meg nem fizetik a püspöknek okozott károkat. ${ }^{37}$

IV. László halálát követően III. András uralkodását támogatta, az 1290. és 1298. évi országygyüléseken is részt vett, az országgyülések határozatait kihirdető oklevelek méltóságsorában a harmadik helyen áll. ${ }^{38}$ Mindemellett az új király 1291. évi gyulafehérvári látogatásakor megerősítette az erdélyi püspökség és az erdélyi káptalan korábbi kiváltságait. ${ }^{39}$ Az 1290-es években a püspök anyagi helyzete is egyre kedvezőbbé vált, ezt mutatják az újabb birtokvásárlások, valamint a gyulafehérvári székesegyház építésének költségei is. ${ }^{40}$ Mindezek alapján, amikor Kán nembeli László 1295-ben megszerezte az erdélyi vajdai címet, az erdélyi püspök bizonyosan egyike volt a legnagyobb erdélyi birtokosoknak. Azt, hogy az erdélyi püspökség anyagi tekintetben is az erdélyi politika komoly tényezője lett, nagymértékben segítették Monoszló nembeli Péter politikai tapasztalatai és udvari összeköttetései. ${ }^{41}$

Meglátásom szerint Péter erdélyi püspök és Kán nembeli László vajda kapcsolata a kisebb konfliktusok ellenére alapvetően harmonikusnak tekinthető. Már Pór Antal 1891. évi tanulmányában arra jutott, hogy az erdélyi egyház a püspök és a vajda jó kapcsolatának köszönhetően nem szenvedett jelentős pusztulást. ${ }^{42}$ Pór meglátása szerint Péter püspök felismerte, hogy sem a püspök, sem a káptalan ereje nem elégséges a szászokkal szemben, ezért olyan vajdáról kell gondoskodni, akinek a tehetsége és az ereje is megvan ahhoz, hogy az erdélyi egyházat és annak birtokait megvédje. ${ }^{43}$ Mindez persze alapvetően megkövetelte a vajdai és püspöki hatalom együttmüködését. Mindketten elismerték és támogatták III. András uralmát, 1298 nyarán részt

34 ERD. OKM. III. 336. sz.

35 Az egri és az erdélyi püspök pereskedésére Máramaros (megye) fölött lásd még HEGYI 2010.b 3., KovÁcs 2019. 307.

36 Kovícs 2015. 10; Monoszló nembeli Péter kapcsolataira utal az az adatunk is, hogy Lodomér esztergomi érsek és János kalocsai érsek szintén megfordultak V. István ifjabb királyi kancelláriájában (Uo. 5.).

37 KovÁcs 2015. 7.; Minden bizonnyal Mikola fiai megfizették a püspöknek a rájuk kiszabott 160 márka bírságot, nem kizárható, hogy Péter püspökségének második felében megfigyelhető építkezések és birtokvásárlások egy részét ebböl finanszírozta. Kovícs 2019. 303.

38 ERD. OKM. I. 472., 570. sz.

39 Uo. 472-474. sz.

40 Uo. 480., 489., 537. sZ.; TEMESVÁRY 1922. 84-85.

41 JAKÓ 2001. 107.

42 PÓR 1891. 434.

43 Uo. 438; Sălăgean szerint a püspök aktív birtokszerzési, várépítési politikája, valamint az, hogy ekkor az erdélyi káptalan (Bő nembeli Mihály), valamint 1294-től a székely ispánság (Bő nembeli Fogas Péter [Zsoldos 2011.a 239.]) élén is rokonai álltak arra utal, hogy Erdélyt a családja hatalma alá akarta hajtani (SĂLĂGEAN 2016. 170171.). Véleményem szerint azonban nem beszélhetünk a püspök ilyen jellegü szándékairól, ennek ellentmond a korábbi vajdákkal való kapcsolata (KovÁcs 2015. 7-9.), valamint az is, hogy Fogas Péter mindössze néhány évig volt székely ispán, illetve, hogy Bő nembeli Mihály 1296-ban zágrábi püspök (Zsoldos 2011.a 103.) lett. Mindez csupán arra enged következtetni, hogy a püspök igyekezett biztosítani az egyházi birtokok védelmét, miközben támogatta rokonait a különböző egyházi és világi tisztségek betöltésében. 
vettek az országgyülésen. ${ }^{44}$ Minden jel szerint III. András 1300 nyarán Kán nembeli Lászlót is bevonta abba a megállapodásba, amely szerint a király törvényesítette az együttmüködésre kész oligarchák helyi hatalmát. ${ }^{45}$

Az első adatunk a püspök és a vajda közötti ellentétre egy 1300. évi oklevélből származik. Eszerint a vajda erőszakoskodott a hunyadi és hátszegi egyházakkal, amiért a püspök és káptalan VIII. Bonifác pápánál (1294-1303) panaszt tettek. ${ }^{46}$ Egy másik oklevél szerint Csete Lőrinc hátszegi ispán a vajda tudtával akadályozta az erdélyi egyháznak járó tizedek beszedését. Minden bizonnyal a püspök és a vajda politikai együttmüködése nem vetett gátat a gazdasági érdekek ütközésének, ami jelen esetben a vajda és az erdélyi káptalan gazdasági ellentétéhez vezetett. ${ }^{47}$

III. András halálát követően Péter püspök érdekelt volt a trón gyors betöltésében, míg az interregnum László vajda helyi hatalma növekedésének kedvezett. Az utolsó Árpád-házi uralkodónk halála, már csak Monoszló nembeli Péter udvari kapcsolatainak köszönhetően is, kihatással volt a püspök és a vajda közötti erőviszonyra. Az ezt követő években nincs rá adatunk, hogy Kán nembeli László szerepet vállalt volna a magyarországi trónkövetelök támogatásában, feltételezhetően az 1301-1306 közötti években magánhatalmát erősítette. ${ }^{48}$

Monoszló nembeli Péter pártállása nehezebben ítélhető meg. Temesváry János szerint az erdélyi püspök Vencel királyt (1301-1305) támogatta, és részt is vett a koronázásán, és csak a Spectator omnium kezdetü bulla kiadását követően állt I. Károly (1308-1342) pártjára. Mindezt az támasztja alá, hogy az erdélyi püspök nem vett részt a Boccasini legátus által összehívott budai zsinaton (1301), valamint az 1302-ben tartott pozsonyi zsinaton. ${ }^{49}$ Kovács Mihai véleménye szerint viszont Péter püspök kezdettől fogva Károly királyt támogatta. Mindezt azzal támasztja alá, hogy rokona (és egykori erdélyi prépost) Mihály zágrábi püspök mindvégig I. Károly támogatói között volt. Egy 1302. évi oklevél tanúsága szerint Péter püspök 100 márkát szánt Boccasini legátus költségeire, ezt azonban az idők viszontagságai miatt nem tudta eljuttatni a Szentszékhez. ${ }^{50}$ Mindezek mögött Kovács egy I. Károlyt támogató, de kiváró politikát sejtet. ${ }^{51}$

Véleményem szerint azonban Kovács Mihai érvelése nem bizonyítja minden kétséget kizáróan, hogy Péter püspök a kezdetektől I. Károlyt támogatta volna. Kristó Gyula szerint, bár a nemzetségnevek divatja csak a 14. század közepével hagyott alább, a 13. század második felében a nemzetségek burkában nagy önállósággal rendelkező, más nemzetségekhez nem igazodó családok születtek meg. Ezt Kristó számos adattal támasztja alá: például 1301-ben Csák nembeli Máté és első unokatestvére, Márk fia, István 1301-ben ellentétes politikai csoportosulásokhoz kapcsolódtak. A rozgonyi csatában pedig az Aba nem több ága is fegyveresen lépett fel az Amadé-fiak ellen. Héder nembeli Köcski Sándor hadjáratot vezetett a király megbízásából a

\footnotetext{
44 Kovács 2015. 8.; KRISTó 1983. 288.

45 Zsoldos 2016. 202.; az egyezmény hátterére és részleteire Zsoldos 2011.b 289-299.

46 DF 277 177.; ERD. OKM. I. 593. sz.

47 Kovács 2016. 96.; Csete Lőrinc hátszegi ispánságára DF 277 428. (Datálására Kovács 2016. 91-92.)

48 KRISTÓ 1983. 288.

49 TEMESVÁRY 1922. 100-106.

50 ERD. OKM. II. 18. sz.;

51 Kovács 2015. 6.
} 
Héder nembeli Köszegiek ellen. ${ }^{52}$ Monoszló nembeli Egyed, Gergely és Péter minden jel szerint próbálták elkülöníteni magukat oldalági rokonaiktól, a nemzetség többi ágától. Ezen törekvésüket mutatja azon néhány oklevél is, amelyben Egyed, Gergely és Péter püspök de genere Thome bani vagy de Filek néven jelentek meg. Erre utal az is, hogy Egyed önállóan rendelkezett javairól, és ezzel kizárta az oldalági rokonait az öröklésből. ${ }^{53}$ Mindezek alapján abból, hogy Mihály zágrábi püspök mindvégig I. Károlyt támogatta, nem következik egyértelmüen, hogy Péter erdélyi püspök is így tett volna. A legátus költségeire szánt - de a legátushoz akkor el nem juttatott - 100 márkát sem tartom kizárólagos érvnek I. Károly támogatása mellett. Maga Kovács jegyezte meg, hogy III. András támogatásától eltekintve Monoszló nembeli Péter nem tért el a pápaság politikai elképzeléseitől. Figyelembe véve azt a tényt, hogy az 1277. évi Gyulafehérvár elleni szász támadást követően a még mindig kiközösített szászoknak több templomot és oltárt is szentelt, Péter püspök személyiségével összeegyeztethetőnek tünik, hogy Vencel király támogatása esetén is megfizette volna a Boccasini legátus költségeire szánt 100 márkát. ${ }^{54}$

Az erdélyi püspöknek ezen pártállását valószínűsíti az Anjoukat támogató Bicskei Gergely és a magyar föpapság között levő ellentét is. Információink szerint Vencelt 11 püspök jelenlétében koronázták meg, és bizonyára nem számolhatunk az Anjou-párti választott esztergomi érsekkel, az üresedésben lévő nyitrai püspökség későbbi Károly-párti püspökével Jánossal, Bö nembeli Mihály zágrábi és Pál pécsi püspökkel, így a számok alapján Vencel koronázásakor még számolhatunk Monoszló nembeli Péter támogatásával Vencel oldalán. 1302. szeptember 10-én János nyitrai püspök számára tett adományt csak István kalocsai érsek, Mihály zágrábi, Pál pécsi és Miklós boszniai püspökök írták át, ${ }^{55}$ minden bizonnyal ekkor ök alkották a püspöki karban Károly pártját. 1303-ban, amikor VIII. Bonifác maga elé idézte a magyar trónért versengő Vencelt és Károlyt, utóbbi képviselői között találjuk István kalocsai érseket, Mihály zágrábi, Tivadar győri és Benedek veszprémi püspököt, valamint Tamás esztergomi, Domokos váci és Miklós vasvári prépostot, valamint István erdélyi (minden bizonnyal gyulafehérvári) főesperest, ${ }^{56}$ utóbbi bizonyára az erdélyi püspök jóváhagyásával. Tehát Péter püspök 1303 tavaszán már I. Károlyt támogatta. Tivadar győri és Benedek veszprémi püspökök is a Spectator omnium kiadását megelőzően állhattak át I. Károly pártjára, csakúgy mint a régi püspökök sorához tartozó Háb váci, Imre váradi és András egri püspökök. ${ }^{57} \mathrm{~A}$ fenti érvek alapján, jómagam úgy látom, hogy Bő nembeli Mihály pártállását Monoszló nembeli Péter pártállásának megítélésénél nem tekinthetjük kizárólagosnak, minden bizonnyal kezdetben Hontpázmány nembeli János kalocsai érsek befolyása alatt Vencelt támogatta, majd János halála után, de még a Spectator omnium kezdetű bulla kiadása elött állt I. Károly pártjára régi püspöktársaival együtt.

1304-ben Monoszló nembeli Péter is aláírta a magyar király és Rudolf osztrák herceg közötti egyezményt. ${ }^{58}$ Mindez Kán nembeli László I. Károly iránti semlegességére, illetve arra enged következtetni, hogy az erdélyi vajda nem gátolta a püspököt az országos politikában való

\footnotetext{
52 KRISTÓ 1979. 148.

53 Kovács 2015. 2-4.

54 Temesváry 1922. 85.

55 ANJOU-OKLT. I. 279. sz.

56 KIss 2018. 1359.

57 RÁCZ 2020. 137-138.

58 ANJOU-OKLT. I. 644. sz.
} 
részvételben. ${ }^{59}$ A püspök szabad mozgásterére utal Varga Tibor Róbert azon észrevétele is, miszerint Monoszló nembeli Péter Kán nembeli László gyámkodása nélkül tudott ellátni igazságszolgáltatói feladatokat, azaz eljártak papi jövedelmeket, végrendeleti és örökségi jogeseteket, valamint hozományt, hitbért, jegyajándékot és leánynegyedet érintő ügyekben. ${ }^{60}$

A püspök és a vajda jó kapcsolatát támasztja alá egy 1306. évi oklevél. ${ }^{61}$ Eszerint Vince kalocsai érsek pápai felhatalmazással utasította Péter erdélyi püspököt, hogy a vajdát és az erdélyi egyházmegye lakóit helyezze egyházi tilalom alá. A kalocsai érsek célja az lehetett a Kán nembeli László által bitorolt Krassó megyei Almás birtok visszaszerzése mellett, hogy a vajdát I. Károly pártjára állítsa. ${ }^{62}$ Péter püspök azonban elutasította a ,frater" vajda kiközösítését, ehelyett fellebbezett a Szentszékhez, arra hivatkozott, hogy a kalocsai érsek a pápától kapott mandátumot vele hivatalos formában nem közölte, valamint hogy az ország elökelői 1307. májusáig fegyverszünetet kötöttek. ${ }^{63}$ Vince kalocsai érsek az ítéletét ki nem hirdető Pétert is kiközösítette, azonban ezt 1307. január 20-án kelt levelében I. Károly és Csák Ugrin ${ }^{64}$ kérésére visszavonta, továbbra is fenntartva az előző levelében Lászlóra és az erdélyi egyházmegyében levő vármegyék lakóira kimondott kiközösítést. ${ }^{65}$

A szakirodalomban azonban felmerült, hogy az 1306. évi oklevél, amelyben Péter erdélyi püspök kifejezi nemtetszését a vajda kiközösítésével szemben, nem a püspök, hanem Kán nembeli László és Bogátradvány nembeli János küküllei fỏesperes kezdeményezésére készült. Ez alapján Tudor Sălăgean azt feltételezi, hogy János fóesperes az idős és beteg püspöktől átvette az erdélyi egyházmegye kormányzását. Az említett föesperes 1303-1306 között a vajdai kancelláriát vezette, majd 1306-1307 között a püspök kancelláriáját, 1306-ban pedig Péter püspök ügyvédjeként tünt fel. Véleményem szerint, a vajda Péter püspök idején nem kormányozhatta saját emberével az erdélyi egyházmegyét, ugyanis azt sem a püspök, sem az erdélyi káptalan nem türte volna szó nélkül. Ezt támasztja alá az is, hogy 1300-ban a hunyadi és a hátszegi egyházakon erőszakoskodó Lászlóval szemben az erdélyi püspök és a káptalan panaszt emelt. ${ }^{66}$ Monoszló nembeli Péter halálát követően a káptalan sem türte szó nélkül, hogy a vajda saját fiát ültesse a püspöki székbe, ez utóbbi esetet a későbbiek során még részletesen tárgyalom. ${ }^{67}$ Mivel János küküllei főesperes szolgálatairól Monoszló nembeli Egyed örökösei, Aba nembeli Lőrinc fiai is megemlékeztek egy oklevélben, sokkal valószínübbnek tűnik, hogy János főesperes az amúgy is együttmüködő püspököt és vajdát is szolgálta. ${ }^{6}{ }^{8}$ Arra, hogy János küküllei föesperes

59 Zsoldos Attila tanulmányában Kán nembeli Lászlót az uralkodóhoz hűséges oligarchák csoportjába sorolja, hiszen sose volt fegyveres konfliktus az erdélyi vajda, illetve I. Károly között. Az egyetlen „konfliktus” a Szent Koronát illetően volt, hiszen László az időközben kezére került korona átadásának árát igyekezett minél magasabban megszabni. (Zsoldos 2017. 28.).

60 VARGa 2003. 219; ANJOU-OKLT. I. 28., 36., 82., 86., 344., 361., 383., 649., II. 244-245., 311., 165. sz. Az ilyen esetek az egyházi bíróságok hatáskörébe tartoztak, világi bíróságok nem foglalkoztak velük, így ezek a perek önmagukban nem, csak a püspökök és oligarchák kapcsolatának viszonylatában utalnak az elöbbi mozgásterére.

${ }^{61}$ ANJOU-OKLT. II. 92. sz.; ERD. OKM. II. 54. sz.

62 UDVARDY 1991. 184.

63 ERD. OKM. II. 54. sZ.; TeMESVÁRY 1922. 108.

64 Csák Ugrin személyére Kristó 1999 41-62.; GaLAmbosi 2017. 289-322.

${ }^{65}$ ANJOU-OKLT. II. 114. sz.; ERD. OKM. II. 57. sz.; KRISTó 2002. 314.

66 ERD. OKM. I. 593. sz.

67 Uo. II. 94. sz.

68 ANJOU-OKLT. IV. 679. sz.; KovÁcs 2015. 8. 
nem a vajda familiárisainak egyike volt, utal az a tény is, hogy a föesperes Péter püspök halálát követően I. Károly kancelláriájában tevékenykedett. ${ }^{69}$

A püspök és a vajda jó kapcsolatára utal Benedek domonkos perjellel való együttmüködésük is. Péter halála után Kán nembeli László először saját fiát akarta a püspöki székbe ültetni, ${ }^{70}$ majd a káptalan tiltakozására és Gentilis pápai legátus nyomására másik két jelöltet állított, akik közül az egyik Péter ágostonos perjel, a másik Benedek budai, korábban gyulafehérvári domonkos perjel volt. Mindez önmagában feltételezi a vajda és Benedek jó kapcsolatát. Arra is van adatunk, hogy Péter püspök szoros kapcsolatot ápolt e két szerzetesrenddel, többször ők adtak ki oklevelet a püspökség peres ügyeiben. ${ }^{71}$ Benedek ózdi főesperes szerint a később megválasztott püspök amicus ac consiliarius bone memorie Petri olim episcopi Transilvani volt. ${ }^{72}$ Ezek alapján Benedek perjel János küküllei főespereshez hasonlóan mind a vajda, mind az erdélyi püspök bizalmasa lehetett. ${ }^{73}$

Kán nembeli László 1307-ben, még Péter püspök halála elött elfogta a trónkövetelö bajor Ottót (1305-1307), ez alkalommal került a kezébe a Szent Korona is. ${ }^{74}$ Az esetet követően 1308. február 19-én a szebeni szász egyetem a sebesi szász dékánság papjaival együtt fegyveresen támadt az erdélyi egyházra. ${ }^{75}$ Ezzel a támadással a szászok Ottó bebörtönzését is meg kívánták torolni, azért éppen a káptalanon, mert Ottó herceg elfogatásában Péter püspök közremüködését vélték felfedezni. ${ }^{76}$ Véleményem szerint Péter püspök Ottó elfogatásában való vélt vagy valós közremüködésétől függetlenül maga a vád, amely szerint értelmi szerzője volt a bebörtönzésnek, is mutatja a püspök és a vajda harmonikus viszonyát.

1307. november 27-én meghalt Péter püspök, amely gyökeres változást eredményezett az erdélyi egyház és a vajda viszonyában. A 13. század elejére az egyházmegye vezetőjének megválasztása kizárólagosan a székeskáptalanok kanonokjait illette meg. A gyakorlatban azonban csak a király által püspöknek felterjesztett klerikust választották meg, jogilag legitimálva az uralkodó akaratát. A 13-14. század fordulóján a királyi hatalom meggyengülésének következtében a magyar székeskáptalanok élhettek (volna) a püspökválasztás jogának tényleges lehetőségével, azonban ekkor az oligarchák tettek kísérletet arra, hogy befolyást gyakoroljanak a püspökválasztásra, hiszen saját területükön már uralkodói jogokat is rendre kisajátítottak. ${ }^{77}$ Így például Kőszegi Henrik királyi tárnokmester 1306-ban elfogatta a pécsi vár várnagyát, átvette a hatalmat, majd kényszerítette a pécsi káptalan kanonokjait, hogy a vár, a város és a székesegyház feletti hatalmat adják át Miklós éneklőkanonoknak. Erre a pécsi káptalan belső viszálya nyújtott lehetőséget, mivel Tamás esztergomi érsek által kinevezett Péter pécsi püspököt a pécsi éneklőkanonok nem fogadta el, inkább magát szerette volna a püspöki székben látni,

69 Uo. 8.; ENGEL 1996. I. 82., 90.; SăLĂGEAN 2016. 268-270.

70 A régebbi szakirodalomban Benedek domonkos perjelt, majd erdélyi püspököt tévesen Kán nembeli László püspökként megválasztott fiával azonosították. Monoszló nembeli Pétert is Kán nembeli László rokonának tekintik, ezért az erdélyi püspöki szék betöltésében egyfajta családi kontinuitást véltek felfedezni (BEKE 1894. 23-24.)

71 ERD. OKM. I. 445., 592., II. 54-55. sz.

72 MVH. I./2. 176; TEMESVÁRY 1922. 120.

73 Kovícs 2015.9.

74 KRISTó 1983. 289., a Szent Korona sorsára az interregnum évei alatt SKORKA 2019. 91-119.

75 KRISTÓ 2002. 311.

76 Somogyi 2010. 248.

77 Koszta - Fedeles 2009. 219. 
ebben néhány pécsi kanonok is támogatta. ${ }^{78}$ Ezt a választási vitát használták ki a Kőszegiek, s vonták fennhatóságuk alá a pécsi püspökvárat. Miklós éneklőkanonok a káptalan pecsétjét magánál tartva, mint adminisztrátor kormányozta az egyházmegyét, éveken át kezében tartva a székesegyházat és az egyházmegye jövedelmeinek nagyobb részét. ${ }^{79}$ 1308-ban pedig Köszegi Miklós törvénytelen fiát, Miklóst választották meg győri püspöknek, ráadásul ez utóbbi esetet V. Kelemen (1305-1314) pápa is jóváhagyta 1311-ben. ${ }^{80}$

Erdélyben sem különbözött a helyzet, amikor Péter püspök halála után az erdélyi székeskáptalan kanonokjai püspökválasztásra gyültek össze, László fogságra vetette őket, a távollevőket erőszakkal visszahozatta, s 1308. január 7-én a püspökválasztásra összegyült kanonokok jelenlétében felolvastatta fia választási levelét. ${ }^{81}$ Sălăgean szerint Kán nembeli László számára Köszegi Henrik fiának, az említett Miklós püspöknek a megválasztása lehetett a minta, ${ }^{82}$ ezt azonban könnyen kizárhatjuk annak ismeretében, hogy Miklós megválasztására csak Tivadar győri püspök 1308. május 1-jét követő halála után kerülhetett sor. ${ }^{83}$ Sokkal inkább nyújthatott mintát az erdélyi vajda számára, ha egyáltalán ilyen jellegü tettekhez mintára volt szüksége, az 1306. évi pécsi püspökválasztás. Az elhúzódó püspökválasztás, valamint Miklós éneklőkanonok támogatása révén Kőszegi Henrik évekig kezében tudta tartani a pécsi egyházmegye jövedelmeit. ${ }^{84}$

Az erdélyi vajda nem véletlenül törekedett megszerezni fia számára az erdélyi püspökséget, hiszen a családi hatalom úgy válhatott még hatékonyabbá, ha a világi és egyházi méltóságok egy kézben összpontosultak. ${ }^{85}$ Minderre már csak azért is szüksége volt, mert az erdélyi püspöki és káptalani birtokok lakói mentesek voltak a vajdai joghatóság alól, ráadásul a püspök és a káptalan a vajda után a legnagyobb birtokosok közé tartoztak Erdélyben. Ennek a jelentőségét növeli, hogy bár az erdélyi vajda számbelileg több erőddel rendelkezett, azonban az erdélyi egyház kezén levő várak elhelyezkedése stratégiailag, különösen az egyházi birtokok szempontjából, jobb volt. ${ }^{86}$ Ennél is fontosabb lehetet azonban Kán nembeli László szempontjából, hogy az egyházi birtokok két fontos vára - Déva és Csicsó - közé ékelődtek be. Mindez szintén arra enged következtetni, hogy a vajdának Monoszló nembeli Péterrel harmonikus volt a viszonya, feltételezhető, hogy Kán nembeli László tartott attól, hogy egy olyan személy kerülhet az erdélyi püspöki székbe, akivel a korábbi jó püspök-vajda viszony nem müködhet.

A vajda komoly befolyását mutatja, hogy az erdélyi káptalan Párizsi Péter kanonok révén csak 1308 decemberében terjesztette be Gentilis legátus elé igényét az újabb püspökválasztásra. ${ }^{87}$ Bár a vizsgálat elkezdődött, de döntésre nem volt szükség, mivel 1309-ben már Kán nembeli László is letett fia püspökségéről. 1309. július 19-én Illés dékánkanonok útján írásban

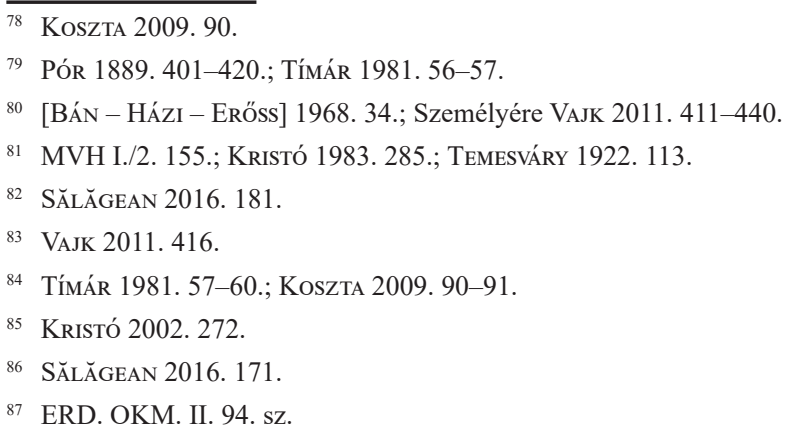


biztosította az erdélyi káptalant, hogy fia kérvényezett (postulatus) mivolta ürügyén többet nem gátolja a káptalant a püspökválasztásban, de a püspökség birtokait csak abban az esetben adja vissza, ha Péter fráter Ágoston-rendi szerzetest, vagy pedig Benedek frátert, a budai domonkosok perjelét választják meg. ${ }^{88}$ A káptalan László engedélyét megkapva július 24-ére tüzte ki a választás napját. ${ }^{89}$

Megválasztásáról 1309. augusztus 17-én értesült Benedek fráter, azonban megerősítése egyrészt a távollévő kanonokok, másrészt a szentszéki követség részéről nem várt akadályokba ütközött. Minden bizonnyal Benedek nem élvezte megválasztásakor a teljes káptalan támogatását, ugyanis a káptalan 24 tagjából csak 15-en voltak jelen megválasztásakor. A legátus udvarában János székesfehérvári prépost, küküllői főesperes ellentmondással élt mind a választás, mind a megválasztott püspök személyét illetően. Ezt később azonban a káptalant képviselő kanonokok beszámolói hatására visszavonta. ${ }^{90}$ Mindezek alapján úgy vélem, hogy Benedeket a káptalan egy gyors döntés következtében, a vajda nyomásának engedve választotta meg püspökévé, amelyet később a távollévő kanonokok is jóváhagytak.

Választásával szemben a pápai ügyhallgatók szeptember 2-án két lényeges kifogást tettek. Az egyik, hogy a választás a kelleténél később történt, ugyanis akár Péter püspök halálától (1307. november 27.), akár a káptalan által Párizsi Péter kanonok útján kijelentetett választási szabadságát követően (1308. december 10.) több mint három hónap telt el, márpedig az egyházi törvények csak ennyi időt hagynak valamely választás megejtésére, ezt követően erre az egy esetre a választás joga a Szentszékre háramlik. ${ }^{91}$ Az ügyhallgatók másik kifogása az volt, hogy az erdélyi káptalan abban az időben, amikor a választást megejtette, egyházi tilalom alatt állt, mert Vince kalocsai érsek szerint a pápai követség fenntartására reájuk kivetett procuratio-t nem fizették meg. Eszerint tehát hiányzott választási képességük, és e kánonellenes eljárásuk miatt ugyancsak a Szentszéket illeti a választás joga. Ha azonban a káptalan tagjai e két pontra 40 napon belül képesek mentséget találni, és a megejtett püspökválasztás ügyében senki nem fog kifogást tenni, akkor szentszéki követség hajlandó igazságot szolgáltatni. ${ }^{92}$

Miután a káptalan értesült a követség kifogásairól, hozzákezdtek a szükséges bizonyítékok összegyüjtéséhez. A püspökválasztás ügyének teljhatalmú képviseletével Benedek ózdi, János kolozsi és Miklós telegdi főespereseket bízták meg. ${ }^{93}$ A megbízottak közül azonban csak Benedek ózdi fóesperes kelt útra, aki 1309 októberének első hetében megjelent az ekkor már Nagyszombaton székelő Gentilis törvényszéke előtt. Bemutatta a szász kerületi dékánoknak és a gyulafehérvári ágostonosok perjelének bizonyságleveleit arról, hogy Péter püspök halála óta 1309. július 19-ig gátolva volt az erdélyi káptalan a püspökválasztásban. Vince kalocsai érsek állításának megcáfolására pedig felmutatták az első évi procuratio megfizetését bizonyító

88 Uo. 131. SZ.; TeMESVÁRY 1922. 116.

89 Sălăgean szerint ezen választás két hónappal később történt, és a pápai legátus vizsgálóbizottsága előtt bemutatott okleveleket is az erdélyi vajda és a vele összejátszó kanonokok hamisítványának vélte, mindez azonban egy oklevél félreértelmezésének köszönhető. (SĂLĂGEAN 2007. 147-157.; HEGYI 2010.a 159.).

90 ERD. OKM. II. 159. sz.; LUPESCU MAKÓ 2017. 282-284.

91 A IV. Lateráni Zsinat (1215) elrendelte, hogy ha a káptalan három hónapon belül nem választja meg a püspököt, akkor erre az esetre nézve elveszíti választói jogát, és a közvetlenül felettes hatóság válik devolúció útján jogosulttá az üresedésben lévő egyházmegye betöltésére (c. 23.) - ERDö 2001. 189.

92 TEMESVÁRY 1922. 117-124.

93 ERD. OKM. II. 153. sz. 
nyugtát. ${ }^{94}$ Végül pedig átnyújtotta a gyulafehérvári Domonkos-rendiek vikáriusának és az Ágoston-rendi remetéknek az együttes nyilatkozatát arról, hogy senki se szólalt fel a püspökválasztás ellen. Miután az erdélyi káptalan bizonyította, hogy a választáskor választási képességének birtokában volt, a pápai követség László vajda káptalan feletti befolyását vitatta. Így 1309. december 16-án azt a kérdést intézték a káptalanhoz, hogy milyen szerepe volt Kán nembeli Lászlónak a püspök megválasztásában. Benedek ózdi főesperes válaszában hangsúlyozta, hogy a káptalan tagjait Benedek buzgó vallásossága ösztönözte, ugyanakkor Kán nembeli László ígéretének a szerepét is elismerte, amely szerint az erdélyi püspökség várait és birtokait visszaadja Benedek megválasztása esetén. ${ }^{95}$ Bár a vizsgálat véget ért, döntésre egyelöre nem került sor, Benedek még hat hónapig nem nyert megerősítést. Ennek oka a Gentilis bíboros és Kán nembeli László között megindult, a Szent Koronáért folyó alkudozásban keresendő. ${ }^{96}$

Gentilis bíboros fő feladatát I. Károly törvényességének elismertetése képezte, azonban továbbra is nagy nehézséget okozott, hogy az Ottótól elvett Szent Korona még mindig Kán nembeli Lászlónál volt. Ennek a visszaszerzése képezte a bíboros egyik legfőbb törekvését. A pesti országgyülést követően meg is indultak a tárgyalások, Buda és Kán nembeli László székhelye, Déva $^{97}$ között. Már 1308 novemberében a vajdánál találjuk a bíboros és az esztergomi érsek megbízásából Miklós aradi prépostot és olvasókanonokját. Ezt követően Imre váradi püspök járt Déván Gentilis követeként. E küldöttek fáradozása azonban nem járt sikerrel. Mivel I. Károly második, 1309. június 15-ei koronázását se tekintette mindenki érvényesnek, ezért Gentilis bíboros mindent elkövetett, hogy Kán nembeli Lászlót a Szent Korona kiadására bírja. Temesváry János nyomán eddig a szakirodalom úgy tartotta, hogy a második koronázást követően küldte Gentilis bíboros az udvarában tartózkodó Benedek választott püspököt a vajdához, amely követség azonban sikertelenül zárult. Ráadásul, mielőtt a bíboroshoz visszatérhetett volna, még Kőszegi Henrik is fogságba ejtette néhány napra. ${ }^{98}$ Ennek azonban ellentmond, hogy az eseményekről beszámoló oklevelet egyrészt 1309 . augusztus 1 . elé datálják, ${ }^{99}$ másrészt Benedek mint a Szent Domonkos-rend szigeti perjele szerepelt, amely tisztségről püspökké választásának elfogadásához le kellett mondania. Így Benedek Kán nembeli Lászlóhoz tett útjára még püspökké választása előtt, minden bizonnyal 1309 tavaszán, vagy kora nyarán kerülhetett sor. ${ }^{100}$

Gentilis tehát I. Károly második koronázását követően, hogy a vajdára hasson, 1309. december 25-én kiközösítette, meghagyva neki, hogy a koronát 1310. február 2-ig, az általa elfoglalt királyi javakat pedig három hónap alatt szolgáltassa vissza. ${ }^{101}$ Ezt követően Benedek frátert 1310 elején ismét Lászlóhoz küldte, azonban ez a második út már sikeresnek tekinthető. A vajda érzékelte az I. Károly oldalán tapasztalható erőgyarapodást, s ha a bíboros által szabott

94 Uo. 156. sz.

95 MVH. I/2. 174-176.; ERD. OKM. II. 159. sz.

96 TEMESVÁRY 1922. 124-127.

97 Kán nembeli László dévai rezidenciájára KRISTó 2001. 37-38.

98 TeMESVÁRY 1922. 127-129.

99 MVH I./2. 335-337.; ANJOU-OKLT. II. 708. sz.

${ }^{100}$ LuPESCU MAKó 2017. 288. Bár nem igazolható minden kétséget kizáróan, de abból a két adatból kiindulva, hogy 1309. májusában a vajda fiáról, mint a püspöki méltóság várományosáról tesz említést, valamint, hogy 1309. július 19-én már hozzájárul, hogy a káptalan püspököt válasszon feltételezhetjük, hogy Benedek követségére a két időpont között került sor (uo. 281.).

${ }^{101}$ ANJOU-OKLT. II. 790. sz.; ERD. OKM. II. 160. sz.; KRISTó 1983. 290.; KRISTó 2002. 315. 
határidőt nem is tartotta be, de 1310. április 8-án kelt oklevelében mégis elismerte I. Károlyt urának. Ugyanebben az oklevélben felajánlotta szolgálatait a királynak, ígéretet tett a korona július 1-jéig történő visszajuttatására, visszaadta a királynak a radnai ezüstbányát, a besztercei, a szebeni és a székely ispánságot, Dés, Kolozs és Szék falvakat az ottani sóbányákkal együtt. ${ }^{102}$ Végül, miután Kán nembeli László visszaadta a koronát, 1310. július 2-án Gentilis bíboros megerősítette Benedek erdélyi püspökké választását. ${ }^{103}$

Az erdélyi püspök megerősítését követően nincs adatunk Kán nembeli László és Benedek püspök kapcsolatáról, mégis néhány okleveles adat segítségével árnyalhatjuk a korszakról, illetve a vajda és az egyház kapcsolatáról alkotott képünket. 1311-ben Benedek erdélyi püspök sokallta a Gentilis pápai követ eltartásáért 450 vagy 500 márka procuratio-t, és a Szentszékhez fellebbezett, hogy a kalocsai érsekség öt más suffraganeusával együtt több jövedelemmel rendelkezik, mint az erdélyi egyházmegye. Mindezt azzal magyarázta, hogy Péter püspök halálát követő mintegy két és fél éves üresedés alatt az erdélyi egyházat jövedelmeitől megfosztották. ${ }^{104}$ Erre enged következtetni egy 1310. évi adatunk is, amely szerint I. Károly a IV. Lászlótól és III. Andrástól nyert tordai sóakna birtokában és adómentességében újra megerősítette az erdélyi káptalant. ${ }^{105}$ Véleményem szerint azonban kétséges, hogy az uralkodó említett adományának érvényt tudtak-e szerezni.

Felmerült a kérdés a szakirodalomban, hogy mi lehetett a jutalom, amelyet Kán nembeli László az uralkodó elismeréséért cserébe, de főleg a Szent Korona kiadásáért kért. ${ }^{106}$ Kristó Gyula szerint az uralkodó ígéretet tehetett arra, hogy László vajda életében nem teszi vizsgálat tárgyává, hogy miként jutott nagyszámú birtokaihoz. ${ }^{107}$ Zsoldos Attila szerint a megegyezés szilárd alapokra épült, hiszen Kán nembeli László megőrizte vajdai hatalmát tartománya felett, I. Károly számára pedig nyilvánvalóan az elismerés, valamint a korona visszaszerzése volt a lényeges kérdés, a vajda által jogtalanul birtokolt királyi javak ügye másodlagosnak számított. ${ }^{108}$ I. Károly 1310 végén Erdélybe látogatott, ami a bajor Ottóval történtek után aligha lett volna lehetséges, ha kettejük között nem állt volna fenn egyfajta bizalmi viszony, amit az sem kezdett ki, hogy Kán nembeli László továbbra is bitorolta a királyi javakat. Egy 1312. évi okleveles adatunk szerint ugyanis Kán nembeli László járt el a kolozsaknai vendégtelepesek ügyében, ${ }^{109}$ miközben ez volt az egyike azon sókamaráknak, amelynek visszaadására ígéretet tett 1310 tavaszán. ${ }^{110}$ Mindezek alapján tehát nem zárható ki, hogy Kán nembeli László a már említett királyi sókamarák mellett az erdélyi egyház sóból származó jövedelmeire is rátette a kezét, minden bizonnyal Monoszló nembeli Péter halálát követő üresedés idején. A kolozsaknai vendégtelepesek feletti ítélkezés pedig arra enged következtetni, hogy az erdélyi vajda, akárcsak a szegedi

\footnotetext{
${ }^{102}$ ANJOU-OKLT. II. 863. sz.; ERD. OKM. II. 162. sz.; KRISTó 1983. 281.; Kristó 2002. 315.

${ }^{103}$ ERD. OKM. II. 169. sz.; KRISTó 1983. 290.; Temesváry 1922. 129-131.

104 ANJOU-OKLT. III. 115. sz.; ERD. OKM. II. 186. sz.; KRISTó 2002. 264.

105 TEMESVÁRY 1922. 134.

${ }^{106}$ ERD. OKM. II. 162. sz.

107 KRISTÓ 1996. 335

${ }^{108}$ I. Károly politikájában a királyi birtokok visszaszerzésével szemben az elismertetés elsőségét hangsúlyozza az az adatunk is, amely szerint Csák nembeli Máténak a király elismerése mellett elegendő volt az uralkodói javak kisebbik, méltányos részét visszajuttatnia a királynak. KRISTó 2003. 301.

109 ANJOU-OKLT. III. 239. sz.; ERD. OKM. II. 195. sz.

${ }^{110}$ Zsoldos 2016. 203.
} 
egyezmény egyes pontjait, I. Károly „,adományát” is figyelmen kívül hagyva tovább bitorolta a tordai sóaknát.

Erre utal az az 1326. évi adatunk is, amely szerint I. Károly András erdélyi püspök ama panaszára, hogy a szent királyok adományából Székaknáról, Kolozsaknáról, Désaknáról és Tordáról az erdélyi püspöknek járó tizedsó szállítását különféle jogtalan vámokkal és illetékekkel akadályozzák, hüséges szolgálataira való tekintettel megerősíti ezeket a korábbi adományokat, és a sótized intézését kiveszi mind az erdélyi vajda, annak officialisai, ispánjai, mind a királyi kamaraispánok és ezek officiálisainak joghatósága alól. Egyidejűleg az uralkodó elrendelte, hogy a mondott helyekröl származó tizedsót, valamint az erdélyi káptalan tordai sóaknájában termelt só ügyében a püspök officialisai szabadon intézkedhessenek, szárazon és vízen, saját vagy idegen fuvarral oda szállíthassák az országban, ahova akarják, minden vámfizetés vagy egyéb illeték és akadályoztatás nélkül. ${ }^{111}$ Ezt támasztja alá, hogy az erdélyi vajda végzett minden olyan feladatot, amellyel korábban a király felruházta, illetve megbízta, ezek közé tartozott a vámszedés is. ${ }^{112}$ Példának okáért a Maroson szállított só után, az Alvincnél szedett vám kétharmada az erdélyi káptalant, míg egyharmada az erdélyi vajdát illette. ${ }^{113}$

A szegedi egyezmény egyes pontjainak figyelmen kívül hagyására, illetve az egyházi sójövedelmek megkaparintására enged következtetni a szebeni prépostság helyzete is. Vízaknán a 9. századtól müködött sómủvelés, az aknák döntő többsége a király birtokában volt, de egyikük, minden bizonnyal a prépostság alapításakor a szebeni prépost birtokába került. A zavaros erdélyi birtokviszonyokra utal, hogy I. Károly 1328-ban vizsgálatot rendelt el, amelynek tárgya, hogy a szebeni prépostság régtől fogva birtokolta és adta-e bérbe vízaknai sóbányáját. ${ }^{114} \mathrm{Az}$ erdélyi káptalan 1328 áprilisában lefolytatta a vizsgálatot, majd ez alapján májusban igazoló jelentést tett az uralkodónak, ${ }^{115}$ amely alapján a király 1330-ban megerősítette a prépostságot a vízaknai sóbányája birtoklásában. ${ }^{116}$ Mindezek alapján közvetlen adatok hiányában is erősen feltételezhető, hogy Kán nembeli László legkésőbb Monoszló nembeli Péter püspök halála után rátette a kezét az erdélyi egyház sójövedelmeire.

Összességében az erdélyi püspökök és Kán nembeli László kapcsolatáról az alábbi következtetéseket vonhatjuk le: Monoszló nembeli Péter és Kán nembeli László vajda kapcsolata alapvetően harmonikusnak tekinthető, a fentebb kifejtett érvek alapján a kisebb konfliktusok ellenére feltételezhető, hogy az erdélyi püspöknek nem csak a vajdával való együttmüködéshez, de az országos politikában való részvételhez és a vallási ügyeket érintő igazságszolgáltatási feladatok ellátásához is elegendő mozgástere volt. Véleményem szerint mindebben szerepet játszott Monoszló nembeli Péter származása és családi háttere, politikai kapcsolatai, illetve a püspöksége alatt megerősödő erdélyi egyház birtokállománya is. A püspökség és a vajda közötti „párharcban” fordulópont lehetett III. András halála, a központi hatalom hiánya mindenképpen Kán nembeli Lászlót hozta kedvezőbb helyzetbe. Péter püspök halálával és a mintegy két és fél éves üresedést követően végképp megváltozott a korábbi erőviszony a vajda és a püspök között, az előbbi javára. Forrásaink elsősorban a

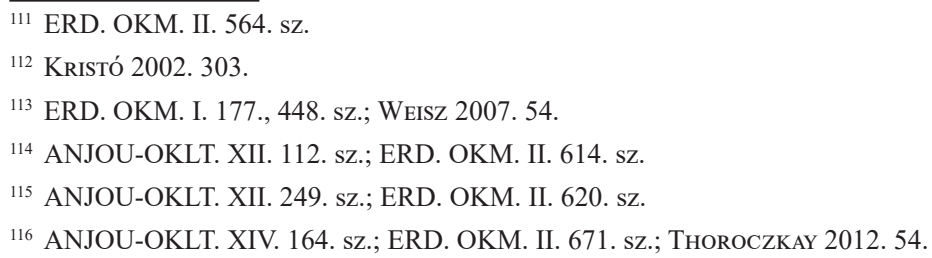


konfliktussal járó helyzeteket örökítették meg, ${ }^{117}$ így mivel az erdélyi egyházmegyét illetően nincs adatunk birtokfoglalásokról, ${ }^{118}$ valamint az 1308. évi erőszakos püspökválasztást követően nincs tudomásunk nagyobb konfliktusról, feltételezhető: Kán nembeli Lászlónak sikerült elérnie Benedek erdélyi püspök „meghódolását”, akaratának érvényesítését a püspökség és annak javai felett. A származás fontosságára utal Erdély következő püspökének a személye is. 1320-ban a káptalan saját prépostját, Balog nembeli Szécsi Andrást választotta püspökké, nem titkolva szándékát, hogy inkább a befolyásos urat kereste, aki saját és rokonsága erejével meg tudja védeni a sokat szenvedett erdélyi egyházat a további zaklatásoktól. ${ }^{119}$

\section{KÁN NEMBELI LÁSZLÓ ÉS AZ ERDÉLYI KÁPTALAN}

A fentiek alapján vizsgáljuk meg, hogy az említetteken túl, hogyan is rekonstruálható az erdélyi székeskáptalan története. Az erdélyi káptalan a vajda és a püspök mellett a középkorban végig egyike volt a legnagyobb erdélyi birtokosoknak, a káptalan Dél-Erdélyben, elsősorban Fehér megyében hozott létre nagy kiterjedésü birtokkomplexumot. ${ }^{120}$ Monoszló nembeli Péter püspöksége idején a káptalan szorosan együttmüködött püspökével, V. István a kanonokok népeit mentesítette a vajdai descensus alól és kivette a vajdai igazságszolgáltatás alól. ${ }^{121}$ Szintén V. István adta az erdélyi kanonokoknak a tordai sóaknát és átengedte részükre a birtokain lakó népek által fizetendő teljes királyi collecta-t. ${ }^{122}$ IV. László pedig apja adományainak megerösítése mellett 1289-ben felruházta a kanonokokat a saját ügyeikben való ítélkezés jogával. ${ }^{123}$ Már Borsa nembeli Roland vajda alatt megszaporodtak az erdélyi káptalant ért jogtalanságoknak és birtokpereknek a száma. IV. László már 1289-ben utasította az erdélyi vajdát, hogy ne akadályozza a kanonokokat az őket illető vám beszedésében. ${ }^{124}$

Kán nembeli László első említése is az erdélyi káptalan egyik 1295. évi birtokperével kapcsolatos. ${ }^{125}$ Egy 1296. évi birtokperben a vajda a káptalan javára ítélt Ludasi Bot fiai ellenében. ${ }^{126}$

117 „Megfigyeléseink arra mutatnak, hogy vandál pusztításba a tartományurak ott kezdtek, ahol elmaradt az egyházi testület irányukba történő feltétlen meghódolása" (KRISTó 1979. 178.).

${ }^{118}$ Ellenben az Erdélyen kívül elhelyezkedő egyházak esetében vannak adataink a bitorlásról, mint például a kalocsai érsekség Almás nevü ismeretlen fekvésü birtoka esetében (ANJOU-OKLT. II. 114. sz.; ERD. OKM. II. 57. sz.), vagy az egresi egyház apátfalvi, szászcsanádi, sorostélyi nevü birtokai, valamint Kisselyk faluban lévő birtokrészei esetében (ANJOU-OKLT. IV. 63. sz.; ERD. OKM. II. 228. sz.). A budai káptalannak 1316-ban visszaadott Lapád is László jogtalan szerzeménye lehetett (KRISTó 2002. 309.). Ennek hátterében véleményem szerint az áll, hogy az Erdélyen, valamint Kán nembeli László tartományán kívül elhelyezkedő egyházak felett a vajda, lévén az adott egyházi intézmény nem a tartománya területén feküdt, nem tudta érvényesíteni az akaratát, befolyását így ezek esetében az egyházi birtokok bitorlásáról forrásaink megemlékeznek a vajda és az egyháziak közötti konfliktusnak, illetve a vajda halála utáni birtokvisszaadásról szóló okleveleknek köszönhetően.

119 Temesvíry 1922. 141.

${ }^{120}$ JAKÓ 2001. 105.; KRISTó 2002. 264. Az erdélyi káptalan az erdélyi Fehér megyében a 13. század végén mintegy 25 birtokkal rendelkezett (Uo. 113.).

${ }^{121}$ ERD. OKM. I. 291. sz.

${ }^{122}$ Uo. 315. sz.

${ }^{123}$ Uo. 447. sz.

${ }^{124}$ Uo. 448. sz.

${ }^{125}$ Uo. 539. sz.

${ }^{126}$ Uo. 550. sZ. 
László vajda és az erdélyi kanonokok közötti birtokviszályra utal viszont az az 1296. évi okleveles adatunk, amely szerint az erdélyi káptalan és László vajda kölcsönösen kibékülve megegyezett Buzd, Bogács és Egurd birtokok ügyében. ${ }^{127} \mathrm{E}$ birtokok értékét az is mutatja, hogy III. András parancsára Kán nembeli Lászlónak 150 nemes eskütárssal kellett volna bizonyítania állításának igaz voltát. ${ }^{128}$ Ahogy azt már fentebb is említettük, 1300-ban a káptalan püspökével együtt emelt panaszt a Szentszéknél a hunyadi és a hátszegi egyházakon hatalmaskodó Lászlóval szemben. ${ }^{129}$ Ezt követően a káptalan és a vajda kapcsolatára Monoszló nembeli Péter püspök haláláig nincs adatunk, leszámítva Bogátradvány nembeli János küküllei föesperes müködését a vajdai kancellárián (1303-1306).

Kán nembeli László és a káptalan közötti kapcsolat következő mérföldkövének a már fentebb kifejtett 1308. évi püspökválasztás tekinthető. A vajda a továbbiakban nem korlátozta legalábbis a jelek szerint - a káptalan tagjainak személyes szabadságát. Ennek ellenére a helyzet csak később normalizálódott. A káptalan Párizsi Péteren keresztül arra kérte Gentilis bíborost, hogy állítsa vissza a káptalan választási jogát, a szentszéki követségtől nyert engedély csekély jelentőségü volt, amíg Kán nembeli László nem mondott le fia megválasztatásáról. ${ }^{130}$ Ezt a jóváhagyást a káptalan 1309. július 19-én kapta meg. ${ }^{131}$ Ekkorra talán a vajda és a káptalan viszonya is rendeződhetett, erre utal, hogy Illés dékánkanonoknak segítséget ígért a Tamás éneklökanonok által elvett állatok és javak visszaszerzéséhez, valamint hogy a káptalan tagjait „,már megismerte és derék embernek tartja őket." ${ }^{132}$

A vajda engedélyét követően a káptalan Benedek domonkos perjelt választotta püspökének. Korábban már tárgyaltuk a püspök megerősítésének folyamatát, azonban a káptalan szempontjából ezzel párhuzamosan egy másik ügy is zajlott a pápai követség udvarában. Ez utóbbi per az erdélyi székeskáptalan és „némely” szász plébánosok között zajlott, ugyanis az erdélyi szászok papjainak egy része az erdélyi püspök joghatósága alá tartozott. A per, amely Gentilis auditora, Sardinea-i Fülöp kánonjogi doktor elött zajlott valójában nem egy, hanem három egymástól különálló per volt, amelyek viszont egyidőben zajlottak Budán. A perek „szétválasztását” Somogyi Szilvia végezte el, eszerint az egyes perek tárgya: 1. A sebesi szász dékánság által az erdélyi káptalannak meg nem fizetett adó; 2. A káptalan ellen az erdélyi hét szász dékánság által elkövetett jogtalanságok; 3. A káptalannak az erdélyi hét szász dékánság által okozott túlkapások és sértések. ${ }^{133}$

Ezekben a perekben Kán nembeli László is érdekelt volt, mivel Péter püspök halála óta a püspöki javakat saját fennhatósága alá vonta. Így az erdélyi káptalan oldalán avatkozott be az erdélyi kanonokok és a szász dékánok közötti perbe. ${ }^{134} 1309$-ben azonban a felperes káptalan

${ }^{127}$ Uo. 546. sz.

${ }^{128}$ Uo. 543. sz.

${ }^{129}$ Uo. 593. sz.

${ }^{130}$ Temesvíry 1922. 113-114.

${ }^{131}$ ERD. OKM. II. 131. sz.

132 ,ipsos cognoscebat et bonos reputabat” - MVH. I./2. 174-175.; ERD. OKM. II. 159. sz.; TeMESVÁRY 1922. 116.

${ }^{133}$ Somogyi 2010. 247.

${ }^{134}$ Varga Tibor Róbert ezt úgy értelmezi, hogy miután az erdélyi székeskáptalan 1309. július 24-én megválasztotta jelöltjét, Benedek domokos perjelt Erdély püspökének, a vajda, hogy „meghálálja” a káptalan „baráti gesztusát”, megpróbált a szászok ellenében a püspökség védelmezöjeként fellépni (VARGA 2011.9.). Varga érvelésének a gyenge pontja, hogy Kán nembeli László „baráti gesztusa” időben megelőzi a püspökválasztás időpontját, tehát a „hálája” okát. Így a „baráti gesztus” okát Kán nembeli László fiának megválasztásában vélem láthatónak, minden bizonnyal ezzel próbálta az erdélyi vajda fia püspöki pozícióját erősíteni. 
és az alperes szászok viszálya már tekintélyes múlttal rendelkezett. A két fél szembenállása a 12. század végére megy vissza, amikor is az Erdély déli határán letelepedő szászok számára III. Celesztin pápa (1191-1198) 1191-ben szabad ,prépostságot” hozott létre Szebenben, amelyet kivett az erdélyi püspök joghatósága alól, és közvetlenül az esztergomi érsek alá rendelt. ${ }^{135} \mathrm{Az}$ exemptio azonban nem volt érvényes a később betelepülőkre, ők nem a szebeni prépostsághoz, hanem az erdélyi püspökséghez tartoztak, és a szebeni prépostsághoz tartozókkal szemben nem mentesültek a tizedfizetés kötelezettsége alól. Éppen ezért folytonos csatározások folytak a terheiktől megszabadulni próbáló többi szászok lakta terület (Szászváros, Szászsebes, Szerdahely, Köhalom, Medgyes, Segesvár) papsága, illetve az idővel megszervezett dékánságok és az erdélyi püspök, valamint a gyulafehérvári székeskáptalan között. ${ }^{136}$

1277. február 21-én Alard fia Gyán egy magánbosszú keretében - legalábbis az erdélyi szász papok Gentilis előtt tett vallomása szerint ${ }^{137}$ - szász fegyveresekkel megrohanta és kifosztotta Gyulafehérvár városát. A székesegyházat elfoglalták, kincstárának ajtaját feltörték, abból az egyházi kincseket elrabolták, a káptalan levéltárát felgyújtották, a székesegyházat pedig rágyújtották az odamenekült kanonokokra, valamint a források alapján kétezer magyar városlakóra, a püspöki város és vidékének lakosait pedig felkoncolták. ${ }^{138}$

Az ellentétek a 14. század elején ismét kiújultak, amit Kán nembeli László és a szászok szembenállása is tovább mélyített. Ekkor ugyanis a korábbi anyagi ellentéteket politikai szembenállás is tetézte, ugyanis a szászokat azzal vádolták, hogy ök hozták be 1305-ben Magyarországra I. Károly ellenében Wittelsbach Ottót, amíg a szászok az erdélyi püspököt és a káptalant vádolták, hogy a vajda a segítségükkel ejtette foglyul a trónkövetelőt. 1308. február 19-én a szebeni szász egyetem a sebesi szász dékánság papjaival együtt fegyveresen támadt az egyházra. ${ }^{139}$ A szászok ezt nem vállalták magukra, a dolog politikai élét tompítva az 1308. februári támadást bizonyos szász plébánosok akciójaként tüntették fel, akik azért fordultak a gyulafehérvári kanonokok ellen, mert azok bizonyos adók miatt a Szentszéknél feljelentést tettek, valamint be akarták börtönözni őket. ${ }^{140}$

A szászok és a káptalan közötti anyagi ellentét eredete a következő: 1283-ban az erdélyi káptalan bérbe adta a Medgyes vidékéről neki járó gabona-, bor-, méh-, és báránytizedet az eceli, berethalmi, riomfalvi, muzsnai, medgyesi, paratélyi, sárosi és kapusi papnak a lakosság számától függetlenül évi 40 márkáért. ${ }^{141}$ 1303. január 9-én Péter püspök közvetítésével a káptalan és a sebesi szász dékánság között létrejött egy egyesség, minden bizonnyal az 1283. évi tizedbérlet módosításaként, amely szerint ezentúl e kerületnek a lakosai a lelkészek, a harangozók és egyházfiak kivételével, a káptalani kiküldött és a kerületi dékán, vagy az egyik pap által a helyszínen megállapított minden hatvan füst után évi adó fejében egy budai értékủ ezüstmárkát tartoznak az erdélyi székeskáptalannak fizetni. ${ }^{142}$ Ezen eseményeket követően a kápta-

${ }^{135}$ A szebeni decanatus jogi helyzetének alakulására KIss 2013. 130-142.; A szebeni társaskáptalan történetére THOROCZKAY 2012. 37-55.

${ }^{136}$ Csukovits 1996. 126-127.; Kiss 2013. 141.

${ }^{137}$ ERD. OKM. II. 117. sz.

${ }^{138}$ ERD. OKM. I. 349., 351. sZ.; TEMESvÁRY 1922. 62.; CsuKovits 1996. 127.; KRISTÓ 2002. $226-227$.

139 ANJOU-OKLT. II. 656. sz.; ERD. OKM. II. 116. sz.

${ }^{140}$ ANJOU-OKLT. II. 661. sz.; ERD. OKM. II. 117. sz.

${ }^{141}$ Uo. I. 399., 445. sz.

142 ANJOU-OKLT. I. 344. sZ.; TeMESvíRY 1922. 105.; Kristó 2002. 264, 310-311. 
lan kérésére 1308-ban super quibusdam iniuriis, offensionibus et excessibus necnon censibus, debitis, decimis, redditibus et rebus aliis a legátus kúriája elé kapott idézést a sebesi, springi, ózdi, kézdi, keresdi, kis- és nagyküküllői esperesi kerületbe tartozó 33 név szerint felsorolt, és a többi szász dékán és plébános. ${ }^{143}$ A szászok azonban nem jelentek meg a kitüzött határidöre. Ennek hátterében a vajda ténykedése állt. 1308 novemberének elején, amikor Miklós aradi prépost Kán nembeli Lászlónál járt Gentilis bíboros követeként, a szász dékánok és plébánosok, valamint a szebeni ispánok és a szász universitas szabad átvonulást kért László vajdától annak területén, amit meg is kaptak. A vajda oklevelével tette közhírré, hogy a fennhatósága alatt álló területen bárki biztonságban utazhat. Miután Miklós prépost elhagyta Erdélyt, a vajda egyetlen oklevele elég volt a közhír semmissé tételéhez. ${ }^{144}$ Eszerint bár a vajda mindenki számára megengedte a szabad átvonulást, de figyelmeztette a szászok közösségét, hogy papjaik jövedelmükből a káptalannak és a püspöknek járó kötelezettségeiknek tegyenek eleget és ne keveredjenek jogvitákba, amelyek súlyosabb következményekkel járhatnak számukra. ${ }^{145}$ A vajda szavát, aki elfogatta Wittelsbach Ottót, valamint fia megválasztása érdekében bezáratta a kanonokokat, ostobaság lett volna figyelmen kívül hagyni. Eközben Benedek ózdi főesperesnek sikerült elérnie, hogy a legátusi auditor a meg nem jelent szász papokat kiközösítse, testületeiket interdictum alá vetette. $^{146}$

A szebeni prépostság dékánja, Giselbert tiltakozott amiatt, hogy László erdélyi vajda akadályozza az erdélyi kanonokokkal pereskedő hét szász káptalan képviselőinek az utazását, mert nem voltak hajlandóak lemondani a fellebbezésröl, emellett közölte, hogy e szász plébánosok engedelmeskednek a legátus parancsainak, valamint költségeinek rájuk eső részét is megtérítik. ${ }^{147}$ Ezt követően a vizsgálat akörül a kérdés körül zajlott, hogy akadályozva voltak-e a szász papok a megjelenésben. Bertoldus sebesi dékán a szász papok képviseletében okleveleket hozott Budára egy szász dékántól, két plébánostól, a szebeni ispotályosoktól és két szebeni ispántól, valamint a szászok egyetemétől, ${ }^{148}$ amelyek álláspontja szerint magyarországi szokás értelmében ugyanolyan teljes hitelre tarthatnak igényt, mint Itáliában a közjegyzői oklevelek. ${ }^{149}$ A káptalan képviselöje, Cingulum-i Fülöp azt az álláspontot képviselte, hogy ezek az oklevelek a bíróság előtt nem szerepelhetnek hiteles bizonyítékként, mivel az alperesek kérésére készültek, csak az ő álláspontjukat képviselik, ráadásul az oklevelek pecsétje nem ismeretes mindenki előtt. Ezt követően a szász papok képviseletét Mevanea-i Vagnolus vette át, aki a magyarországi szokásokról való tájékozódás után hat pontban foglalta össze az oklevelek hitelességéről vallott véleményét. Azonban a káptalan ügyvédje az első pont ${ }^{150}$ kivételével nem fogadta el Vagnolus állításait. ${ }^{151}$

\footnotetext{
${ }^{143}$ UGDS 240. sz.; ERD. OKM. II. 97. sz.

144 Somogyi 2010. 251., 258-259.

${ }^{145}$ ANJOU-OKLT. II. 492. sz.; ERD. OKM. II. 89. sz.; Csukovits 1996. 127.

${ }^{146}$ ERD. OKM. II. 96. sz.

${ }^{147}$ ANJOU-OKLT. II. 645. sz.; ERD. OKM. II. 111. sz.

${ }^{148}$ Uo. 102. sz.

149 A 14. század eleji hitelesnek tekintett oklevél kritériumaira lásd: KumoroviTz 1936. 63-66.

${ }^{150} \mathrm{Az}$ első pont: „Általános szokás (generalis consuetudo) Magyarországon, hogy a prelátusok saját pecséttel megpecsételt oklevelei hitelesek (fidem faciunt), mind az egyházi, mind a világi bíróságok elött." A további pontokra lásd: Csukovits 1996. 128.

151 Uo. 127-128.
} 
Az ellentétes álláspontok szükségessé tették, hogy a kérdésben tanúkihallgatást rendeljenek el. A perrel kapcsolatos tanúválogatás nem volt véletlen, ugyanis 1309. június 15-én került sor I. Károly második, budai koronázására, így minden bizonnyal ennek is köszönhető a tanúk budai tartózkodása, valamint az, hogy idézésüket követően rövid időn belül megjelentek a legátus bírósága előtt. Vagnolus kérdéspontjai alapján 10 tanút hallgattak ki, ${ }^{152}$ azonban a szász plébánosok leveleit csak János erdélyi kanonok ismerte el hitelesnek. ${ }^{153}$ Így a szász plébánosok védelmében tevékenykedő Vagnolusnak nem sikerült elérnie a célját, azaz a szászok által bemutatott oklevelek hitelességének elismerését. Közben a dékánságok a pert Rómába fellebbezték, ezért a bíróság a pert a szeptember 29. utáni első tárgyalási napra halasztotta el. Ezt követően a tárgyalások félbeszakadtak, feltételezhetően az erdélyi káptalan tagjait választott püspökük, Benedek elismertetése kötötte le.

Az erdélyi káptalan és a szász plébánosok közti tizedvita az 1320-as években újult ki. 1322ben XXII. János pápa (1316-1334) újabb vizsgálatot rendelt el, ${ }^{154} 1323$-ban I. Károly megparancsolta valamennyi szásznak, hogy az erdélyi egyháznak ellenszegülő valamennyi papot püspökük iránti engedelmességre szorítsák, vagy egyházukból távolítsák el. ${ }^{155}$ A tizedek ügyében folyó perrel párhuzamosan 1327-ben indított akciót András püspök az elidegenedett egyházi birtokok, tizedek és egyéb jövedelmek visszaszerzésére, XXII. János pápa pedig Tamás szebeni prépostot bízta meg az erdélyi káptalan ügyének támogatásával. ${ }^{156} \mathrm{~A}$ szász plébánosok és az erdélyi káptalan közti per fellebbezése végül 1328-ban zárult le, eszerint a sebesi dékánság papjai visszatérnek a püspök és káptalan iránti engedelmességre, fellebbezésüket visszavonják, és ezt követően 200 márka finom ezüst büntetés lefizetése mellett visszamenőleg is megfizetik a káptalannak járó, korábban meg nem fizetett censust, azaz minden 60 füst után évenként egy budai márka súlyú finom ezüstöt. ${ }^{157}$ A kúria döntésében azt javasolta, hogy a két fél egyezzen ki egymással valamelyik hiteleshely előtt, ez 1330. május 30-án történt meg a váradi káptalan előtt. ${ }^{158}$

Az erdélyi káptalan és Kán nembeli László közötti kapcsolatról 1310-et követően nincs adatunk, azonban a káptalan későbbi birtokperei igazolni látszanak a korszakot jellemző zavaros birtokviszonyokat. ${ }^{159}$ Egy 1336. évi okleveles adatunk is ezt erősíti, ebben az erdélyi káptalan Buzd nevü birtokának határait ismertetik. ${ }^{160}$ Mindez felveti a kérdést a fentebb már említett 1296. évi, a káptalan és Kán nembeli László közötti megegyezést illetően, amely szerint a vajda a Küküllő mentén kárpótolja a káptalant Buzd, Bogács és Egurd birtokokért cserébe. ${ }^{161}$ Arról ugyanis nincs adatunk, hogy Buzd birtok mikor került vissza a káptalan birtokába. Felmerülhet,

\footnotetext{
${ }^{152}$ Gál csázmai prépost, János erdélyi kanonok, János budai éneklőkanonok, János kői prépost, kalocsai kanonok, István veszprémi prépost, Ágoston zágrábi püspök, Benedek csanádi püspök, László szerémi püspök, Péter pécsi püspök, valamint Pál szepesi prépost. A tanúvallomásokra lásd ERD. OKM. II. 98. sz.; CsuKoviTs 1996. 129-132.

153 János erdélyi kanonok mind a hat pontra azt vallotta: igaz, maga is sokszor látta az egyházi bíróságokon. Válasza azért is érdekes, mert azzal az ellenfelet erősítette. (Uo. 130.)

154 ANJOU-OKLT. VI. 873. sz.

${ }^{155}$ Uo. VII. 447. sz.

${ }^{156}$ Uo. IX. 293. sz.; ERD. OKM. II. 598. sz.; JAKÓ 2001. 109.

${ }^{157}$ ERD. OKM. II. 618. sz.

${ }^{158}$ ANJOU-OKLT. XIV. 303. sz.; ERD. OKM. II. 676. sz.

${ }^{159}$ Uo. II. 396., 403., 896., 898. sz.

${ }^{160}$ Uo. II. 898. sz.

${ }^{161}$ ERD. OKM. II. 543., 546. sz.
} 
hogy az említett kárpótlás megtörtént-e, illetve, hogy Buzd birtok mikor és hogyan került vissza a káptalan kezére. Egy lehetséges magyarázatként a XXII. János pápa által megbízott Tamás szebeni prépost működését tarthatjuk számon, aki arra kapott megbízást, hogy szerezze vissza az erdélyi káptalan számára a korábban az egyház sérelmére elidegenített birtokokat. ${ }^{162}$ A zavaros erdélyi birtokviszonyokra enged következtetni, ha minderre közvetlen adatok nem is állnak rendelkezésre, hogy I. Károly 1336 tavaszán kezdett foglalkozni az erdélyi püspökség és káptalan birtokügyeinek a rendezésével, egy éves általános parancslevelet adva az erdélyi káptalan birtokainak határával vagy pereivel kapcsolatos ügyekben. ${ }^{163}$

A következőkben, mintegy kontrollforrásként az erdélyi egyház helyzetére vegyük röviden szemügyre a nyitrai egyházmegye esetét Csák nembeli Máté oligarchával.

\section{EGY MÁSIK PÜSPÖKSÉG EGY OLIGARCHA ÖLELÉSÉBEN: NYITRA}

Jelen alfejezet címe mindenféleképpen magyarázatra szorul. Ahhoz ugyanis, hogy az erdélyi püspökség, valamint a székeskáptalan és Kán nembeli László kapcsolatáról minél teljesebb képet tudjak adni, szükségesnek éreztem egy másik tartományuraság, oligarchauralom rövid bemutatását. Választásom az északnyugat-magyarországi oligarcha, Csák nembeli Máté területére esett, mivel a forrásadottságokat és szakirodalmat tekintve is ez az egyik legjobban adatolt tartományuraság. Azonban Csák nembeli Máté tettei nehezen vonhatóak párhuzamba Kán nembeli László erdélyi „,egyházpolitikájával”, ez indokolja, hogy a nyitrai püspökség és „oligarchája” viszonyát külön tárgyaljuk.

Az északnyugat-magyarországi oligarcha, Csák nembeli Máté először a pozsonyi egyházzal került szembe. 1297-ben Máté szerviensei a pozsonyi prépostot és káptalant Turne (vagy Csukárd) birtokból kiüzték és azt maguknak bitorolták. ${ }^{164} 1323$-ban a pozsonyi egyház visszakapta a csallóközi Bélt, Deákit és a Vág és a Dudvág között fekvő Taksonyt. ${ }^{165}$ Az oligarchák leverését követően még 1327-ben is arról olvashatunk, hogy a pozsonyi egyházat megillető és az egyháznak járó tizedet, adókat, jövedelmeket, földeket, házakat néhányan eltitkolták az egyház elöl, mindezeket igyekeztek visszatartani. ${ }^{166}$ 1297-ben jelezte VIII. Bonifác pápának Pannonhalma apátja, hogy Csák nembeli Máté és mások az apátságot különböző jogtalanságokkal zaklatják, megfosztják jövedelmeitől, birtokaitól és váraitól. ${ }^{167}$ XXII. János intézkedett arról (sikertelenül), hogy a garamszentbenedeki egyház tulajdonába minél hamarabb visszakerüljenek a Csák nembeli Máté familiárisai révén elrabolt javak. A Nyitra megye keleti részén, valamint Bars megyében birtokkal rendelkező kolozsi monostor esetében közvetlen források híján a történetírásunk joggal utalt arra I. Károly 1327. évi birtokvisszaadásából kiindulva, hogy a kolozsi egyház javai is Csák nembeli Máté kezére kerültek. ${ }^{168}$ Csák nembeli Máté központjához, Tren-

\footnotetext{
${ }^{162}$ ANJOU-OKLT. IX. 293. sz.; ERD. OKM. II. 598. sz.

${ }^{163}$ Uo. II. 892. sz.

${ }^{164}$ MES II. 481. sz.

${ }^{165}$ Uo. III. 54. sz.

${ }^{166}$ Uo. III. 178. sz.

${ }^{167}$ ERDÉLYI - SöRÖs 1903. 83.

${ }^{168}$ CD VIII./3. 74. sz.
} 
csénhez közeli fekvésü szkalkai apátról tudott, hogy meghódolt az északnyugat-magyarországi oligarcha elött, kiközösítése után is szolgálva öt. ${ }^{169}$

A szakirodalom eltérő álláspontokat fogalmazott meg azt illetően, hogy Csák nembeli Máté mikor foglalta el a nyitrai egyház javait. Kristó Gyula feltételezése szerint az oligarcha folyamatosan csipkedett le a nyitrai püspökség birtokaiból. Egy 1302. évi okleveles adat rendkívül sötét képet festett a nyitrai egyház helyzetéről. Eszerint I. Károly 1302. évi adományát megelőző három évben a király vetélytársai és hűtlenei által a tizedekben, vámokban, birtokokban és más jogokban szánalmasan leromboltatott, így az egyház a pusztulás szélére jutott. ${ }^{170}$ Csák nembeli Máté 1317-1318 elött teljes befolyással rendelkezett a nyitrai egyház és káptalanja felett. A trencséni oligarcha megfosztotta János nyitrai fópapot ${ }^{171}$ bíráskodási jogától, ráadásul a püspök ellen vádaskodóknak bizonyítás nélkül mindent elhitt, ellenben a püspök panaszait nem méltányolta. Mindemellett a pecsétek dénárjaira 15 márkát szedett be évente a püspök jobbágyaitól. Csák nembeli Máté hatalmát mutatja, hogy amikor a püspök 60 márkáért Bécsből posztót vásárolt, a trencséni oligarcha magának tartotta meg a vásárolt posztó felét, valamint, hogy a püspököt saját költségén futárként késztette szolgálatra. ${ }^{172}$ Egy 1310 . évi okleveles adat szerint Ábrahám comes két birtokát a nyitrai püspöknek és káptalanának adta. ${ }^{173}$ Amikor Máté erről tudomást szerzett a birtokon fekvő jobb épületeket és házakat elszállíttatta, az ott hátramaradtakat felégette, és a birtokokat nem népesítette be. ${ }^{174}$

A nyitrai püspökséget a legerősebb és legnagyobb kárt okozó támadás Kristó szerint 13161317-ben érte, amit Kádár Tamás meggyőző érveléssel új időpontra, 1313-ra datál. ${ }^{175}$ Ezt az akciót Kristó álláspontja szerint az eredményezte, hogy János püspök Máté iránti megalázó pozícióját megelégelve feltételezhetően szabadulni igyekezett abból. Ennek következményeként a trencséni oligarcha felégette Nyitra városát és a nyitrai székesegyházat, elfoglalta és leromboltatta a püspök nyitrai várát. Mindemellett a Nyitra és Trencsén megyére kiterjedő nyitrai püspöki, káptalani birtokok Máté kezébe kerültek, az egyházi jövedelmeket is ő bitorolta, az egyházi jobbágyokat a számára végzendő robotmunkára kényszerítették. ${ }^{176} \mathrm{Az}$ oligarchát kiközösítő 1318. március 3-án kelt oklevél részletesen felsorolja Csák nembeli Máté „bünlajstromát”. Eszerint Máté a fent említetteken túl felégette Chekee, Kurtueles és Billa püspöki falvakat, Paska püspök halálát követően a Trencsén faluban levő püspöki kúriát magának foglalta le. A püspök jövedelmeinek kisajátításán felül Máté familiárisai 70 ökröt hajtottak el Nyitráról. A püspök tiszteletének teljes hiányát mutatta, hogy Máté familiárisa, Kacsics nembeli Mihály fia, Simon mester az oligarcha jelenlétében meg akarta ölni a nyitrai püspököt. Nem csak János püspököt, de jobbágyait is jelentős károk érték, az említett oklevél beszámol a jobbágyok javainak elvételéről, terményük learatásáról, valamint a kaszálók lekaszálásáról. Szintén az említett oklevélből tudjuk, hogy Máté officialisai különböző munkákra, a tapolcsányi árok ásására,

\footnotetext{
${ }^{169}$ Uo. VIII./2. 58. sZ.; KRISTó 1973. 38-40.

${ }^{170}$ MES II. 514.; ANJOU-OKLT. I. 278. sz.

171 Személyére KÁDÁr 2017.

172 ANJOU-OKLT. V. 48. sz.

${ }^{173}$ ANJOU-OKLT. II. 878. sz.

${ }^{174}$ ANJOU-OKLT. V. 48. sz.; KRISTó 1973. 40-41.

175 KÁDÁR 2017. 12-13.

${ }^{176}$ CD VIII./2. 181-183; ANJOU-OKLT. V. 49. sz.
} 
várfalépítésre, makk és zab gyűjtésére a vadaskert vadjai számára, különféle szállításokra, mészoltásra, vízvezeték és ciszterna készítésére, szántásra, sarlózásra, betakarításra vitték és kényszerítették a nyitrai püspök jobbágyait. ${ }^{177}$ A fentiek alapján Kristó úgy vélte, hogy Csák nembeli Máté célja a nyitrai püspök megfélemlítése, teljes behódoltatása volt. ${ }^{178}$

1297-ben meghallt Paska nyitrai püspök ${ }^{179}$ de öt János csak évekkel később követte a püspökség élén. Minden bizonnyal ezt a hosszabb, üresedéssel járó időszakot a nyitrai egyház nem vészelte át szenvedés nélkül. János nyitrai püspököt végig ott találjuk I. Károly oldalán, másképpen fogalmazva Csák nembeli Máté ellenzékében. 1308. november 10-én a Csák nembeli Máté és Gentilis legátus között lezajló kékesi találkozón is jelen volt utóbbi kíséretében, ${ }^{180}$ 1317-ben pedig jelen volt Komárom ostrománál. Így aztán talán nem is csodálkozhatunk a püspök és az oligarcha rossz viszonyán, a nyitrai pusztítás oka talán nem a püspök behódoltatása volt, hanem az oligarcha bosszúja amiatt, hogy a püspök nem volt hajlandó „együttmüködni” vele. Csák nembeli Máté lényegében korlátlan föpapi jogokat gyakorolt, a püspökség és káptalan birtokain különböző jogtalan adókat vetett ki. A nyitrai káptalan ugyanakkor bölcs belátással viszonyult a trencséni nagyúrhoz, 1312 közepén teljesítették Máté egy birtokba iktatásra vonatkozó utasítását, az üggyel kapcsolatos kiadványban nagyságos férfiúnak (magnificus vir), illetve nagyságos fejedelemnek (magnificus princeps) nevezték. 1321-ben meghalt Csák nembeli Máté, így János püspök ténylegesen is elfoglalhatta egyházmegyéjét, hátralévő éveiben a püspöki jogainak érvényesítése, a püspöki és káptalani elorozott és idegen kezekben levő birtokainak és javadalmainak visszaszerzése várt rá.

\section{ÖSSZEGZÉS}

Mindezeket összevetve a fentebb leírtakkal az alábbi megállapítások tehetőek:

A források és a szakirodalom tükrében Kán nembeli Lászlót mind III. András, mind I. Károly „hüséges oligarchájának” tekinthetjük, igaz, utóbbi esetében sokkal passzívabb az erdélyi vajda szerepe. Monoszló nembeli Péter püspöksége idején mind a püspökségnek, mind a káptalannak szinte zavartalan volt a viszonya az erdélyi vajdával, az 1300. évi hunyadi és hátszegi egyházak feletti erőszakoskodást leszámítva nincs forrásunk arra, hogy a káptalan, a püspök és a vajda között bárminemü konfliktus lett volna. Csák nembeli Máté és János nyitrai püspök példájával ellentétben az erdélyi vajda 1295-ben a káptalan javára ítélt egy birtokperben, majd 1296-ban maga folytat pert a káptalannal, mindez egy legalább semleges viszonyt feltételez.

Monoszló nembeli Péter minden bizonnyal jó kapcsolatot ápolt az erdélyi vajdával, ráadásul önálló politikai mozgástérrel rendelkezett és a vajda gyámkodása nélkül tudott egyházi bíróság alá tartozó ügyekben ítélkezni. Mindebben szerepet játszhattak a püspök családi kapcsolatai, személyes képességei és sikeres politikai tevékenysége. Mindezek lehetővé tették az erdélyi püspökség és a káptalan birtokainak hatékony védelmét az erdélyi vajda hatalmával szemben.

\footnotetext{
177 ANJOU-OKLT. V. 48. sz.

${ }^{178}$ Kristó 1973. 41-42., 131.

${ }^{179}$ Zsoldos 2011.a 93.

180 KÁDÁR 2017. 8.
} 
Monoszló nembeli Péter szerepéből kifolyólag Kán nembeli László az erdélyi püspökség birtokaira, kiváltságaira, valamint jövedelmeire minden bizonnyal a Péter püspök halálát követő időszakban tette rá a kezét. Az erdélyi források híján Csák nembeli Máté és a nyitrai egyház példája szemléltethetné számunkra, hogyan foszthatja ki egy oligarcha egy adott terület egyházát. Hivatalba kerülése után mind Benedek erdélyi püspök, mind János nyitrai püspök arra panaszkodik, hogy az egyházat javaiból teljesen kifosztották, tehát a káptalanok püspök hiányában nem voltak képesek sem a káptalani, sem a püspöki birtokok és jövedelmek megvédelmezésére. Mivel azonban Kán nembeli László kegyetlenkedéseiről nem maradtak fent források, ezért feltételezhetö, hogy az erdélyi oligarcha intézkedései visszafogottabbak voltak, mint a trencséni oligarcháé. A fentebbiek tükrében biztosnak tartom, hogy az egyházak sójövedelmeit Kán nembeli László élete végéig a kezében tartotta.

A fentiek alapján feltételezhető, hogy 1308-tól a vajda akarata érvényesült az erdélyi püspökség és a káptalan felett, Kán nembeli László és Benedek püspök korábbi kapcsolatából és a vajda püspökválasztásra gyakorolt szerepéből kifolyólag az erdélyi püspök (hallgatólagos) együttmüködésével.

Jelenleg forrásaink tükrében elsősorban a püspökök és oligarchák kapcsolata vizsgálható. Feltételezésem szerint a kisebb egyházi intézményeknek nem volt elég erejük az ellenálláshoz, ezért inkább meghódoltak az erdélyi vajda akarata előtt. Erre utal az is, hogy az erdélyi egyházaknál nincs adat a birtokfoglalásról, ellenben Kán nembeli László tartományán kívüli központtal rendelkező Kalocsa és Egres esetében van. A szebeni prépostsággal való konfliktusra alig, a kolozsmonostori apátsággal való konfliktusra pedig egyáltalán nincs forrásunk, de a szegedi egyezményben a király számára visszaadott javak, valamint a későbbi idők zavaros birtokviszonyai és birtokperei, illetve az oklevelekben emlegetett a 14. század első két évtizedét jellemző zavaros állapotok miatt feltételezhető, hogy Kán nembeli László érvényesíteni tudta akaratát az erdélyi egyházak felett.

\section{FELHASZNÁLt IRODALOM}

ANJOU-OKLT. (1990-): Anjou-kori oklevéltár I.- (1301-). Szerk. Almási Tibor et al. Budapest-Szeged.

BÁN JÁNOS - HÁZI JENŐ - ERőss István (1968): A győri püspökök sora. In Bánk József (szerk.): Győregyházmegyei Almanach. Győr, Győri Egyházmegyei Hatóság. 21-79.

BeKe AnTAL (1894): Az erdélyi egyházmegye képe a XIV. század elején. (Az 1332-1337. évi pápai tizedjegyzék világánál). Különlenyomat a »Magyar Sion« 1894. évf.-ból. Esztergom.

CD (1829-1844): Codex diplomaticus Hungariae ecclesiasticus ac civilis. I-XI. Ed. Georgius Fejér.

CsuKovits ENIKŐ (1996): Egyházi és világi oklevelek hitelessége a szentszéki bíróságok előtt. In Kovács András - Sipos Gábor - Tonk Sándor (szerk.): Emlékkönyv Jakó Zsigmond születésének nyolcvanadik évfordulójára. Kolozsvár, Erdélyi Múzeum Egyesület. 126-134.

DF: Magyar Országos Levéltár. Diplomatikai Fényképgyüjtemény 
ENGEL PÁL (1996): Magyarország világi archontológiája. I-II. História Könyvtár. Kronológiák, adattárak 5. Budapest, MTA Történettudományi Intézete.

ERdÉlyi LÁSZló - Sörös Pongrácz (1903): Második korszak. A pápák és a zsinatok reformáló törekvései. 1243-1404. A Pannonhalmi Szent-Benedek-Rend története. 2. Budapest, Pannonhalmi Szent-Benedek-Rend.

ERD. OKM. (1997-2008): Erdélyi okmánytár. Oklevelek, levelek és más írásos emlékek Erdély történetéhez. I-IV. (1023-1372). Regesztákban jegyzetekkel közzéteszi: Jakó Zsigmond - Hegyi Géza - W. Kovács András. A Magyar Országos Levéltár kiadványai II. Forráskiadványok 26., 40., 47., 53. Budapest, Akadémiai Kiadó.

ERDö PÉTER (2001): A püspökök megválasztása a Decretum Gratiani szerint. A kijelölés kritériumai. In Erdő Péter: Egyházjog a középkori Magyarországon. Budapest, Osiris Kiadó. $182-199$.

FÜGEDI ERIK (1977): Vár és társadalom a 13-14. századi Magyarországon. Értekezések a történeti tudományok köréből. Új sorozat 82. Budapest. MTA Történettudományi Intézete.

Galambosi Péter (2017): Csák Ugrin, a hüséges tartományúr. Fons 24. évf. 3. sz. 289-322.

GERICS JózSEF (1987): A korai rendiség Európában és Magyarországon. Budapest, Akadémiai Kiadó.

HegYi GÉza (2010a): Új utak a román történetírásban? Erdélyi Múzeum 72. 1-2. sz. 157-160.

HEGYI GÉZA (2010b): Egyházigazgatási határok a középkori Erdélyben. I. közlemény. Erdélyi Múzeum 72. évf. 3-4. sz. 1-32.

Hervay Ferenc LeVEnte (2001): Abencések és apátságaik története a középkori Magyarországon. In Takács Imre (szerk.): Paradisum plantavit. Bencés monostorok a középkori Magyarországon. Pannonhalma, Pannonhalmi Bencés Főapátság. 461-547.

Homonnai Sarolta (2003): János kalocsai érsek szerepe III. András kormányzatában. In Weisz Boglárka (szerk.): Középkortörténeti Tanulmányok. A III. Medievisztikai PhD-konferencia (Szeged, 2003. május 8-9.) elöadásai. Szeged, Szegedi Középkorász Mühely. 33-48.

JAKó ZsigmOND (1990): A kolozsmonosotori apátság és jegyzőkönyvei a szekularizációig. In Jakó Zsigmond: A kolozsmonostori konvent jegyzökönyvei, 1289-1556. I. kötet 1289-1484. Magyar Országos Levéltár kiadványai, II. Forráskiadványok 17. Budapest, Akadémiai Kiadó. $17-165$.

JAKÓ Zsıgmond (2001): Az erdélyi püspökség középkori birtokairól. In Erdély a keresztény magyar királyságban. Kolozsvár, Erdélyi Múzeum Egyesület. 105-115.

JANITS [Borsa] IvÁN (1940): Az erdélyi vajdák igazságszolgáltató és oklevéladó müködése 1526-ig. Budapest, Egyetemi Nyomda.

KÁDÁR TAMÁs (2017): (III.) János nyitrai püspök (1302-1328) életútja. Magyar Egyháztörténeti Vázlatok 1-2. sz. 5-21.

Kiss Gergely (2013): Királyi egyházak a középkori Magyarországon. Thesaurus Historiae Ecclesiasticae in Universitate Quinqueecclesiensi 3. Pécs, Pécsi Tudományért Kulturális Egyesület. 
Kiss Gergely (2018): VIII. Bonifác és Magyarország (1290-1303). A pápai hatalmi legitimációs elképzelések és kormányzat összefüggései. Századok 152. évf. 6. sz. 1353-1376.

KoszTA LÁszLó (2009): A 14. század közepéig: a püspökök és városuk. In Fedeles Tamás Sarbak Gábor - Sümegi József (szerk.): A Pécsi egyházmegye története I. A középkor évszázadai (1009 - 1543). Pécs, Fény Kft. 57-107.

Koszta LÁszló - Fedeles Tamás (2009.): A pécsi székeskáptalan. In Fedeles Tamás - Sarbak Gábor - Sümegi József (szerk.): A Pécsi egyházmegye története I. A középkor évszázadai (1009 - 1543). Pécs, Fény Kft. 214-330.

Kovács MiHai (2015): „Semper meliora prospiciuntur et utiliora attenduntur”. Monoszló nb. Péter erdélyi püspök társadalmi és politikai kapcsolatai. Erdélyi Múzeum LXXVII. kötet 1. füzet. 1-13.

Kovács Minai (2016): Csete Lőrinc, László vajda és az erdélyi egyház kapcsolata egy kiadatlan oklevél tükrében. Turul 89. évf. 3. sz. 91-97.

Kovács Minai (2019): „Ut Dei ecclesia in suo statu tuta permaneat et in suis bonis sit tranquilla” Monoszló nb. Péter erdélyi püspök birtokszervezői és egyházkormányzati tevékenysége. In Fedeles Tamás - Hunyadi Zsolt (szerk.): Szent Márton és Benedek nyomában. Tanulmányok Koszta László emlékére. Fontes et libri 3. Szeged-Debrecen, „Magyarország a középkori Európában" kutatócsoport. 294-309.

KovÁCs VIKTóRIa (2019): Alter ego domini papae Nicolai III. Fülöp fermói püspök, szentszéki legátus magyarországi tevékenysége (1279-1281). In Kiss Gergely (szerk.): Varietas delectat. A pápai-magyar kapcsolatok sokszínüsége a 11-14. században. De LegatOnline Könyvek 1. Pécs, PTE BTK TTI Középkori és Koraújkori Történeti Tanszék. 117-166.

Kristó GyUla (1973): Csák Máté tartományúri hatalma. Budapest, Akadémiai Kiadó.

KRISTÓ GyUla (1979): A feudális széttagolódás Magyarországon. Budapest, Akadémiai Kiadó.

Kristó Gyula (1983): Kán László és Erdély. In Kristó Gyula: Tanulmányok az Árpád-korról. Nemzet és emlékezet. Budapest, Magvető Könyvkiadó. 269-300.

Kristó Gyula (1988): A vármegyék kialakulása Magyarországon. (Nemzet és emlékezet). Budapest, Magvető Könyvkiadó.

KRISTÓ GyUla (1996): Erdély 1315-ben. In: Kovács András - Sipos Gábor - Tonk Sándor (szerk.): Emlékkönyv Jakó Zsigmond születésének nyolcvanadik évfordulójára. Kolozsvár. Erdélyi Múzeum Egyesület. 333-342.

KRISTÓ GyULA (1999): I. Károly király főúri elitje (1301-1309). Századok 133. évf. 1. sz. 41-62.

KRISTÓ GYUlA (2001): Tartományúri rezidenciák Magyarországon (1301-1320). Acta Universitatis Szegediensis. Acta Historica 115. 33-40.

Kristó Gyula (2002): A korai Erdély (895-1324). Szegedi Középkortörténeti Könyvtár 18. Szeged, Szegedi Középkorász Mühely.

KRISTÓ GYULA (2003): I. Károly király harcai a tartományurak ellen. Századok 137. évf. 2. sz. 297-347.

Kumorovitz Lajos Bernát (1936): Az authentikus pecsét. Turul 50. évf. 3-4. sz. 45-68. 
LuPeSCU MAKó MáRIA (2017): Benedek, az erdélyi egyházmegye első szerzetespüspöke. In Csurgai Horváth József (szerk.): Az elsö 300 év Magyarországon. A Domonkos-rend a középkorban. Székesfehérvár, Alba Civitas Történeti Alapítvány. 277-294.

MES (1874-1999): Monumenta ecclesiae Strigoniensis I-IV. Coll. et edd. Ferdinandus Knauz et alii. Strigonii.

MVH (1885): Monumenta Vaticana historiam regni Hungariae illustrantia. I/2. Acta legationis cardinalis Gentilis (1307-1311). Pór Antal bevezető tanulmányával. Budapest.

PóR ANTAL (1891): László erdélyi vajda (1291-1315). Rajzok Erdély múltjából a középkorban. Erdélyi Múzeum 8. évf. 6. sz. 433-481.

RáCz György (2020): Az egyházi elit változásai. In Csukovits Enikő (szerk.): Az Anjoukor hatalmi elitje. Magyar Történelmi Emlékek. Értekezések. Budapest, Magyar Történelmi Társulat és Bölcsészettudományi Kutatóközpont Történettudományi Intézet. 133-162.

SăLĂgean, Tudor (2007): Un voievod al Transilvaniei: Ladislau Kán (1294-1315). ClujNapoca, Argonaut.

SĂLĂGEAN, Tudor (2016): Transylvania in the Second Half of the Thirteenth Century. LeidenBoston, Brill.

SKorka RenÁTa (2019): A Szent Korona kalandos körutazása az interregnum éveiben (13011310). In Pálffy Géza (szerk.): A Szent Korona hazatér. A magyar korona tizenegy külföldi útja (1205-1978). Magyar Történelmi Emlékek. Értekezések. Budapest. 91-119.

Somogyi SzILVIA (2010): Információáramlás és a közhír keletkezése egy 14. század eleji egyházi bírósági per vallomásainak tükrében. Kút 9. évf. 2. sz. 246-260.

TemesváRY JÁNOS (1922): Erdély középkori püspökei. Kolozsvár, Minerva Irodalmi és Nyomdai Müintézet.

TÍMÁR GYÖRGY (1981): Pécs Károly Róbert-kori püspökei. In Csigi Imre - Kneip István (szerk.): A pécsi egyházmegye schematizmusa 1981. Pécs, Pécsi Szikra Nyomda. 52-66.

THOROCZKay GÁBor (2012): A szebeni prépostság történetének főbb kérdései a XIV. század közepéig. Fons 19. évf. 1. sz. 37-55.

UGDS: Zimmermann, Franz-Werner, CARL (1892): Urkundenbuch zur Geschiscte der Deutschen in Siebenbürgen. Hermannstadt.

Udvardy JózSEF (1991): A kalocsai érsekek életrajza. Dissertationes Hungaricae ex historia Ecclesiae XI. Köln, Görres Gesellschaft.

VAJK ÁDÁM (2011): „Mibe került ezen hűségi levél?” Kőszegi Miklós győri püspöksége és az országos politika. In Nemes Gábor - Vajk Ádám (szerk.): In labore fructus. Jubileumi tanulmányok Győregyházmegye történetéből. A Győri Egyházmegyei Levéltár kiadványai, Források, feldolgozások 13. Győr, Győri Egyházmegyei Levéltár. 411-440.

VARGA Tibor RóBerT (2003): Adatok a 14. századi szentszéki bíráskodásra Erdélyben. In Weisz Boglárka (szerk.): Középkortörténeti Tanulmányok. A III. Medievisztikai PhD-konferencia (Szeged, 2003. május 8-9.) elöadásai. Szeged, Szegedi Középkorász Mühely. 215-226. 
VARGA TiBor RóBert (2011): Az állam és az egyház kapcsolata a 14. századi Erdélyben. Magyar Egyháztörténeti Vázlatok 23. évf. 3-4. sz. 5-18.

WeIsz Boglárka (2007): Megjegyzések az Árpád-kori sóvámolás és -kereskedelem történetéhez. Acta Universitatis Szegediensis. Acta Historica 125. 43-57.

Zsoldos AtTILA (2011a): Magyarország világi archontológiája 1000-1301. (História Könyvtár. Kronológiák, adattárak 11.) Budapest, MTA Történettudományi Intézete.

Zsoldos AtTila (2011b): III. András hat nádora. In Erösségénél fogva várépitésre való. Tanulmányok a 70 éves Németh Péter tiszteletére. Szerk. Juan Cabello - C. Tóth Norbert. Nyíregyháza, 2011.b Szabolcs-Szatmár-Bereg Megyei Önkormányzat Múzeumok Igazgatósága. 289-299.

Zsoldos AtTILA (2012): Hűséges oligarchák. In Baráth Magdolna - Molnár Antal (szerk.): A történettudomány szolgálatában: Tanulmányok a 70 éves Gecsényi Lajos tiszteletére. BudapestGyőr, Magyar Országos Levéltár - Győr-Moson-Sopron Megye Győri Levéltára. 347-354.

Zsoldos AtTila (2015): Miért éppen Károly? In Certamen II.: Elöadások a Magyar Tudomány Napján az Erdélyi Múzeum-Egyesület I. Szakosztályában. Szerk. Egyed Emese, Bogdándi Zsolt, Weisz Attila. Kolozsvár, Erdélyi Múzeum Egyesület. 183-193.

Zsoldos ATtila (2016): Erdélyi háborúk a 14. század elején. In Pósán László - Veszprémy László (szerk.): Elfeledett háborúk. Középkori csaták és várostromok (6-16. század). Budapest, Zrínyi Kiadó. 198-231.

Zsoldos AtTILA (2017): Királyi hatalom és oligarchák Erdélyben a 13-14. század fordulóján. In Kovács Kiss György (szerk.): Félmúlt-jelen: Erdélyben - Európában (1926-2016). Kolozsvár, Korunk - Komp-Press. 21-38. 